\title{
Provenance and Tectonic Setting of Late Lower Cretaceous (Albian) Kazhdumi Formation Sandstones (SW Iran)
}

\author{
Bijan Noori ${ }^{*}$, Nader Kohansal Ghadimvand1, Bahram Movahed1, \\ Mohammadreza Yousefpour ${ }^{2}$ \\ ${ }^{1}$ North Tehran Branch, Islamic Azad University, Tehran, Iran \\ ${ }^{2}$ Iranian Offshore Oil Company, Tehran, Iran \\ Email: "b_noori2002@yahoo.com
}

Received 22 June 2016; accepted 5 August 2016; published 8 August 2016

Copyright @ 2016 by authors and Scientific Research Publishing Inc.

This work is licensed under the Creative Commons Attribution International License (CC BY). http://creativecommons.org/licenses/by/4.0/

(c) (7) Open Access

\section{Abstract}

Provenance and tectonic setting of the Late Lower Cretaceous (Albian) sandstones in SW Iran have been interpreted on the basis of geochemistry (major and trace elements) of 35 samples from Iranian offshore oil fields (Soroosh, Nowrooz, Foroozan and Hendijan). Geochemically, trace-element concentrations, such as $\mathrm{La}$, Th, Sc and $\mathrm{Zr}$, and ratios, such as $\mathrm{La} / \mathrm{Sc}, \mathrm{Th} / \mathrm{Sc}, \mathrm{La} / \mathrm{Co}$, and $\mathrm{Th} / \mathrm{Co}$, of sandstones from Kazhdumi Formation at four localities indicate that they were derived from felsic source rocks and deposited in a passive continental margin. Most major and trace element contents of Kazhdumi sandstones are generally similar to upper continental crust (UCC) values. However, some samples are depleted in major and trace elements (such as $\mathrm{K}_{2} \mathrm{O}, \mathrm{Na}_{2} \mathrm{O}$, Sr and Ba) relative to UCC, which is mainly due to absence or smaller amount of Na-rich plagioclase and K-feldspar and also paucity of clay minerals, which is possibly due to intense weathering and recycling. Enrichments in $\mathrm{Zr}$, negative $\mathrm{Sr}$ anomalies and $\mathrm{Th} / \mathrm{U}$ ratios higher than 4 for Kazhdumi sandstones are further evidence for recycled sources. The study of paleoweathering conditions based on chemical index of weathering (CIW) indicates a moderate to intense weathering of first cycle sediments, or it may alternatively reflect recycling under semi-arid to semi-humid climate conditions in Kazhdumi sandstones. The results of this study suggest that the main source for the Kazhdumi sandstones is likely located in uplifted shoulders of a rifted basin (Neo-Tethys) in its post-rift stage (Arabian basement).

\section{Keywords}

Provenance, Geochemistry, Tectonic Setting, Albian, Kazhdumi Formation, Burgan, SW Iran

\footnotetext{
"Corresponding author.
}

How to cite this paper: Noori, B., Ghadimvand, N.K., Movahed, B. and Yousefpour, M. (2016) Provenance and Tectonic Setting of Late Lower Cretaceous (Albian) Kazhdumi Formation Sandstones (SW Iran). Open Journal of Geology, 6, 721-739. http://dx.doi.org/10.4236/ojg.2016.68055 


\section{Introduction}

The goal of provenance studies is to deduce the characteristics of sediment source areas. The various types of source rocks produce different suite of detrital minerals which reveal the character of that rock from which the suites have originated [1]. However, the geochemical composition of clastic rocks is widely used to understand the composition [2]-[5], evaluate weathering processes [6]-[8], and to develop paleogeographic reconstructions of source regions [9]-[11]. Trace elements (e.g., Nb, Ni, V, Co, Y, La, Th, Sc and Zr) in clastic sedimentary rocks are considered to be immobile under conditions of weathering, diagenesis and moderate levels of metamorphism, and are commonly preserved in sedimentary rocks [12] [13]. Therefore, such trace elements might constitute well-established provenance and tectonic setting indicators [12] [14].

Since most of petroleum reservoirs in Iran are hosted in carbonate rocks [15] [16] less attention has been paid to the siliciclastic sediments, especially in relation to provenance studies. In the present study, we used the geochemistry of sandstones and shales that make-up the Kazhdumi Formation in the offshore oil fields, SW Iran (Figure 1). The objectives of this study are to evaluate the source area composition, tectonic setting and paleoweathering conditions during deposition of the Kazhdumi Formation. The data will help us to expand and improve models for the evolution of the Late Lower Cretaceous (Albian) siliciclastic rocks of the Middle East.

\section{Regional Geological Setting}

The Burgan Formation, Lower Cretaceous (Albian) sands and shales, is lateral equivalent of the Kazhdumi

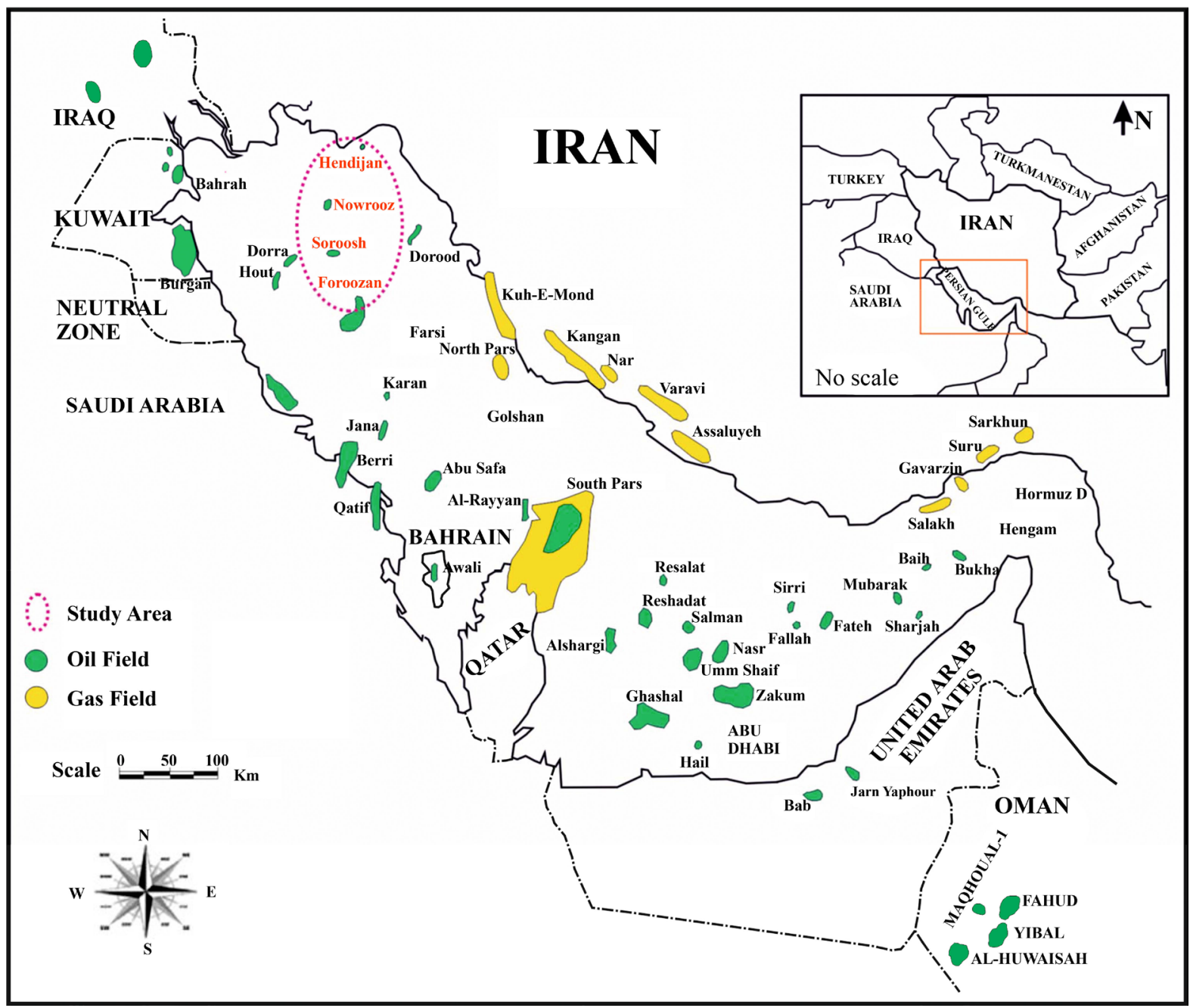

Figure 1. Location map of the Persian Gulf, study area showed on the map (modified after Mashhadi et al., [26]). 
Formation in the northwestern side of the Persian Gulf. Kazhdumi formation and its equivalents (such as Nahr Umar Formation; Safaniya and Khafji Members) form important reservoir rock in several supergiant and many giant oil fields [17]-[20]. The Great Burgan Field in the Kuwait has been ranked as the world's second largest oil field (after Ghawar field) and mainly produces from the Burgan clastics. As well as, this clastic unit is widespread and forms an important reservoir and minor source rock in SW Iran, southern Iraq, Kuwait, NE Saudi Arabia and a minor reservoir in offshore Qatar [21] (Figure 1 and Figure 2).

Glynn Jones, 1948 (in Van Bellen et al., [22]), first used the name "Nahr Umr Formation” to Describe a sandy and shaly interval between the Aptian limestones (Shuaiba Fm.) and the late Albian limestone (Mauddud Fm.) in south Iraq. The Burgan Formation was introduced and described first by Owen and Nasr [23] in the Burgan Field (well No\#113) and it consists of several tens to a few hundred of meters of sands, shale, ooid ironstone and some limestone [20] [21].

Al-Fares [24] reported the existence of a major hiatus within the Albian clastics (traditionally named Burgan Formation). Subsequently, he suggested a redefinition of the Burgan Formation in offshore Kuwait. He proposed that the "Unnamed Clastics or Shuaiba Clastics" between Burgan and Shuaiba Formations should be defined as a new formation. A current difficulty in the study of Burgan Formation is the absence of good and well-studied outcrop analogues. As well as, the difficulties arise from the fact that this formation is barren of fossils.

Similarly, the Albian clastics (Kazhdumi equivalents) in offshore Iran are known and named as Burgan Formation, based on the Kuwait stratigraphic nomenclature scheme. The Soroosh, Nowrooz and Foroozan fields are the main Burgan reservoirs in Iranian territories that are located in offshore Zagros. In Iran, the Burgan Formation has been informally subdivided into the sand dominated lower (part B) and shale-dominated upper (part A) Burgan members. The thick lower sandy member is main reservoir in this formation in most fields [18] [19].

Generally, the Kazhdumi formation has approximately $210 \mathrm{~m}$ thickness in study area. Thickness of the Kazhdumi Sand units (part A and B) at wells ranges from 60 to $126 \mathrm{~m}$ with average of 97 meters. Kazhdumi Formation is separated from the underlying Dariyan (Shuaiba) Formation by a regional erosional unconformity of late Aptian age (Figure 3). Scott et al. [25] recognized duration of the unconformity around 2.2 million years, whereas Alfares et al. [24] determined 6 - 11 million years hiatus based on nano-fossil study. The upper contact with the Lower Sarvak (Mauddud) is gradational.

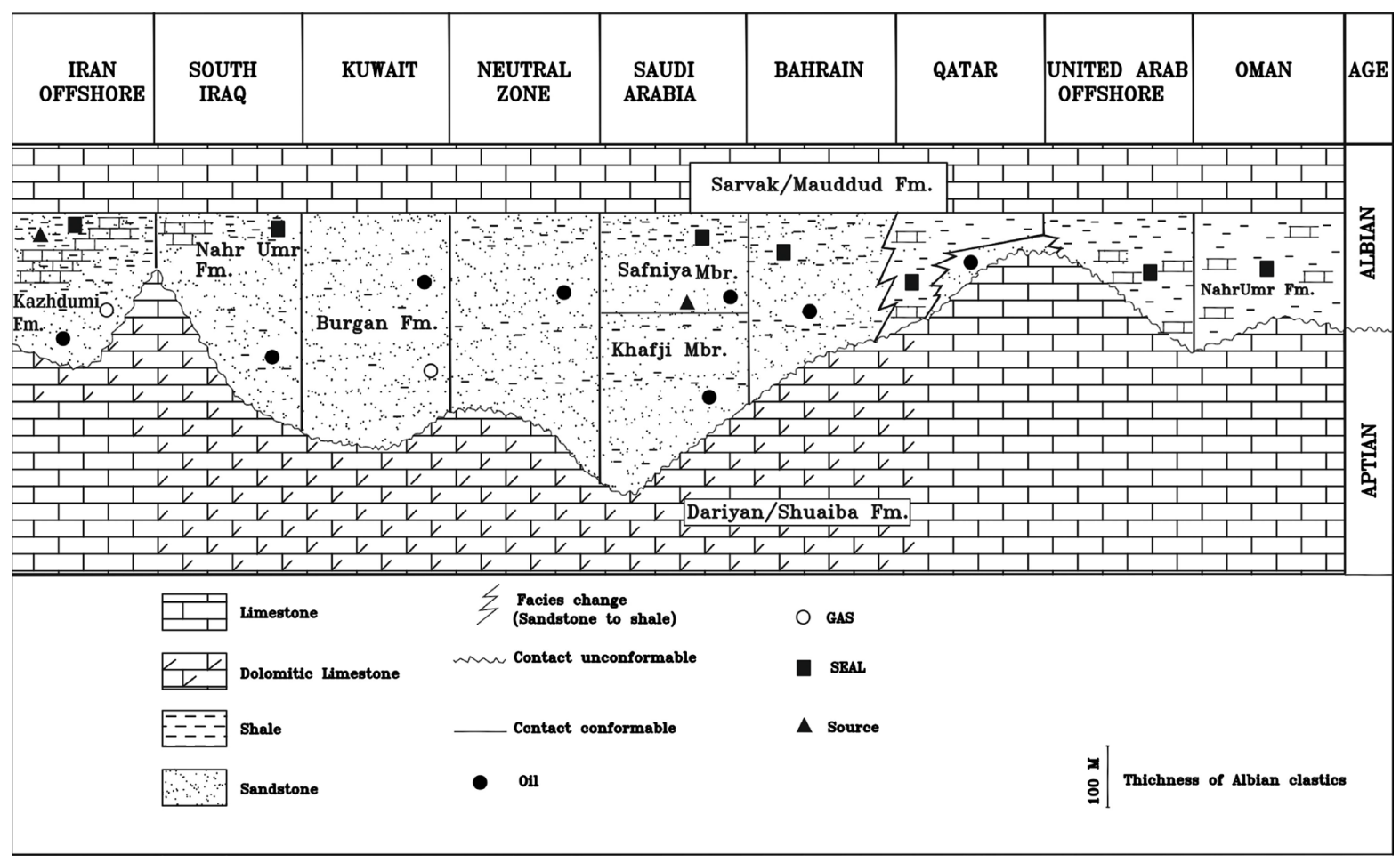

Figure 2. Lithostratigraphy of the Albian sequence in the Persian Gulf (modified after Alsharhan [21]) (Figure 1 represents the location of the mentioned localities). 


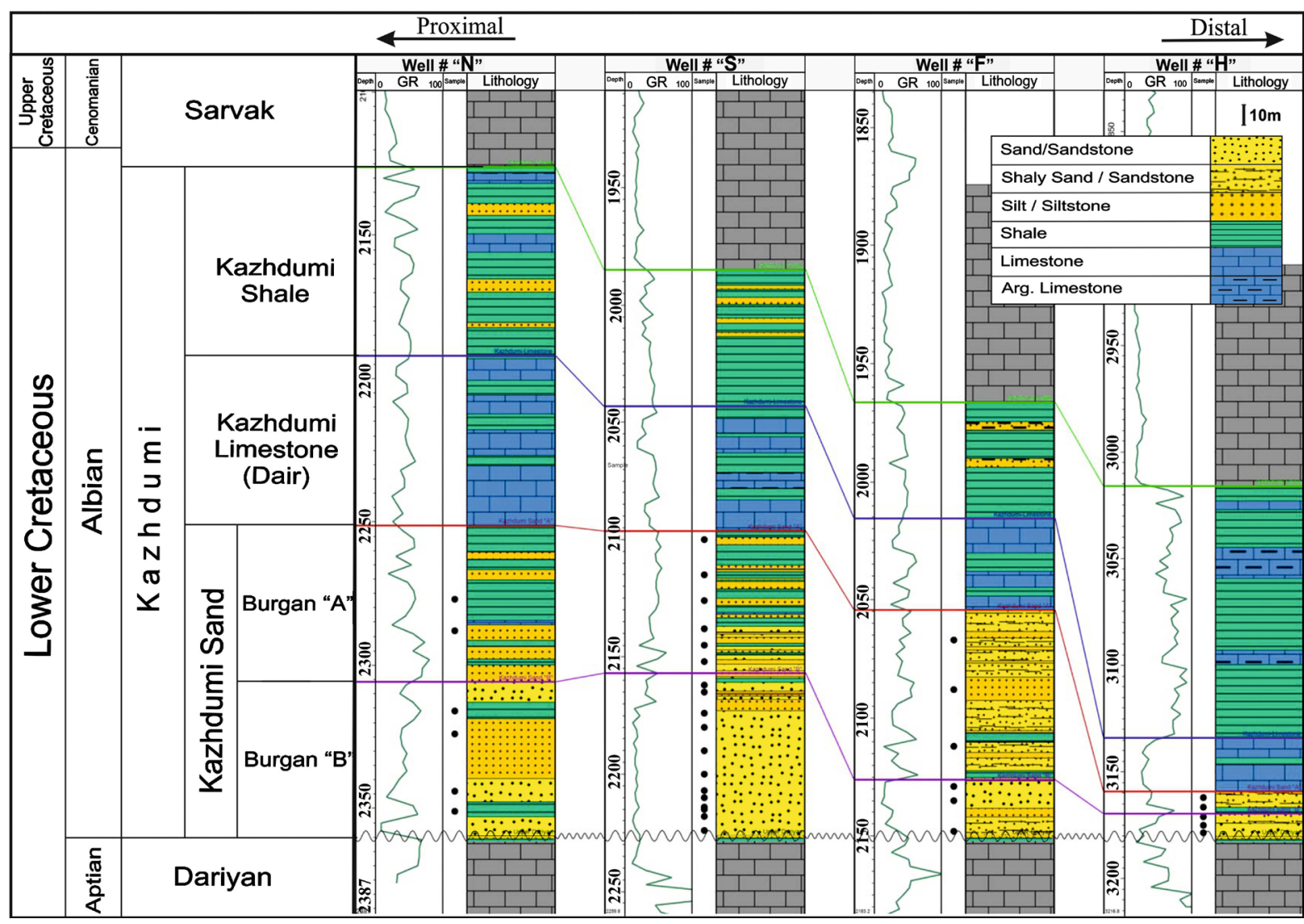

- Depth of samples

Figure 3. Lithostratigraphic sections of the Late Lower Cretaceous (Albian) Kazhdumi Formation at Nowrooz, Soroosh, Foroozan, and Hendijan oil-fields (the wells N, S, F, H respectively).

\section{Analytical Methods}

In this research, four subsurface sections of the Kazhdumi Formation were measured and sampled at Soroosh, Nowrooz, Foroozan and Hendijan oil fields (Figure 3). Over 640 samples of sedimentary rocks were collected from the cored interval of Kazhdumi Formation in above mentioned oil fields. We studied texture, fabric and composition of samples thin sections with optical microscopy. The selected samples were mainly poorly to well-sorted and very fine to coarse grained sand-size. In general, petrographic studies of samples show that, according to Folk [27] classification, these sandstones are mainly quartz arenites, except some samples that they are classified as sublitharenite.

Whole-rock chemical analysis for 35 samples, which include 18 samples from $150 \mathrm{~m}$ core in Soroosh, 6 samples from $28 \mathrm{~m}$ core in Nowrooz, 5 samples from $6 \mathrm{~m}$ core in Hendijan and 6 samples from cutting in Froozan oil fields. Analysis were performed by XRF (MAGIX-PRO) and ICP-OES at the laboratories of the Geological Survey of Iran. The results are provided in Appendix 1 and Appendix 2, respectively.

\section{Results}

\subsection{Geochemistry}

The major and trace element concentrations of Kazhdumi Formation at Soroosh, Nowrooz, Foroozan and Hendijan oil fields are listed in Appendix 1 and Appendix 2, respectively.

\subsection{Major Elements}

The Major element distributions reflect the mineralogy of the studied samples. Sandstones are higher in $\mathrm{SiO}_{2}$ content than shales (Figure 4). The clearly quartz-rich sandstones have $\mathrm{SiO}_{2}$ content that range between $71.7 \mathrm{wt} \%$ 
and $97.1 \mathrm{wt} \%$. They are also depleted of $\mathrm{P}_{2} \mathrm{O}_{5}$, the alkalis $\left(\mathrm{Na}_{2} \mathrm{O}\right.$ and $\left.\mathrm{K}_{2} \mathrm{O}\right)$ and alkali earth elements $(\mathrm{MgO}$ and $\mathrm{CaO})$. This parallel depletion can be attributed to the weathering conditions in the source area [28]. Similarly, shales are higher in $\mathrm{K}_{2} \mathrm{O}, \mathrm{Fe}_{2} \mathrm{O}_{3}$ and $\mathrm{TiO}_{2}$ contents than sandstones (except sideritic sandy samples are higher in $\mathrm{Fe}_{2} \mathrm{O}_{3}$ ), which reflect their association with clay-sized phases [29] [30]. $\mathrm{Al}_{2} \mathrm{O}_{3}$ abundances were used as a normalization factor to make comparisons among the different lithologies, because of its immobile nature during weathering, diagenesis, and metamorphism (e.g., Bauluz et al., [31]). In Figure 4, major oxides are plotted against $\mathrm{Al}_{2} \mathrm{O}_{3}$. Average UCC (upper continental crust) and PAAS (post-Archean Australian shale) values [32] are also included for comparison. Among other major elements, $\mathrm{Fe}_{2} \mathrm{O}_{3}, \mathrm{MgO}, \mathrm{K}_{2} \mathrm{O}, \mathrm{TiO}_{2}$ and $\mathrm{P}_{2} \mathrm{O}_{5}$ are consequently showing positive correlations with $\mathrm{Al}_{2} \mathrm{O}_{3}$, whereas $\mathrm{CaO}, \mathrm{Na}_{2} \mathrm{O}$ and $\mathrm{MnO}$ do not exhibit a trend (Figure 4). The positive correlations of the major oxides with $\mathrm{Al}_{2} \mathrm{O}_{3}$ indicate that they are associated with clay minerals [33].

The Kazhdumi Formation samples were normalized to UCC [32] and are given in Figure 5 Relative to UCC the concentrations of most major elements in the sandstones were generally similar, except for $\mathrm{Na}_{2} \mathrm{O}$ and $\mathrm{K}_{2} \mathrm{O}$, with consistently yields much lower average relative concentration values (Figure 5(a)). The depletion of $\mathrm{Na}_{2} \mathrm{O}$ and $\mathrm{K}_{2} \mathrm{O}$ in samples can be interpreted by absence or smaller amount of Na-rich plagioclase and K-feldspar in them, consistent with the petrographic data.

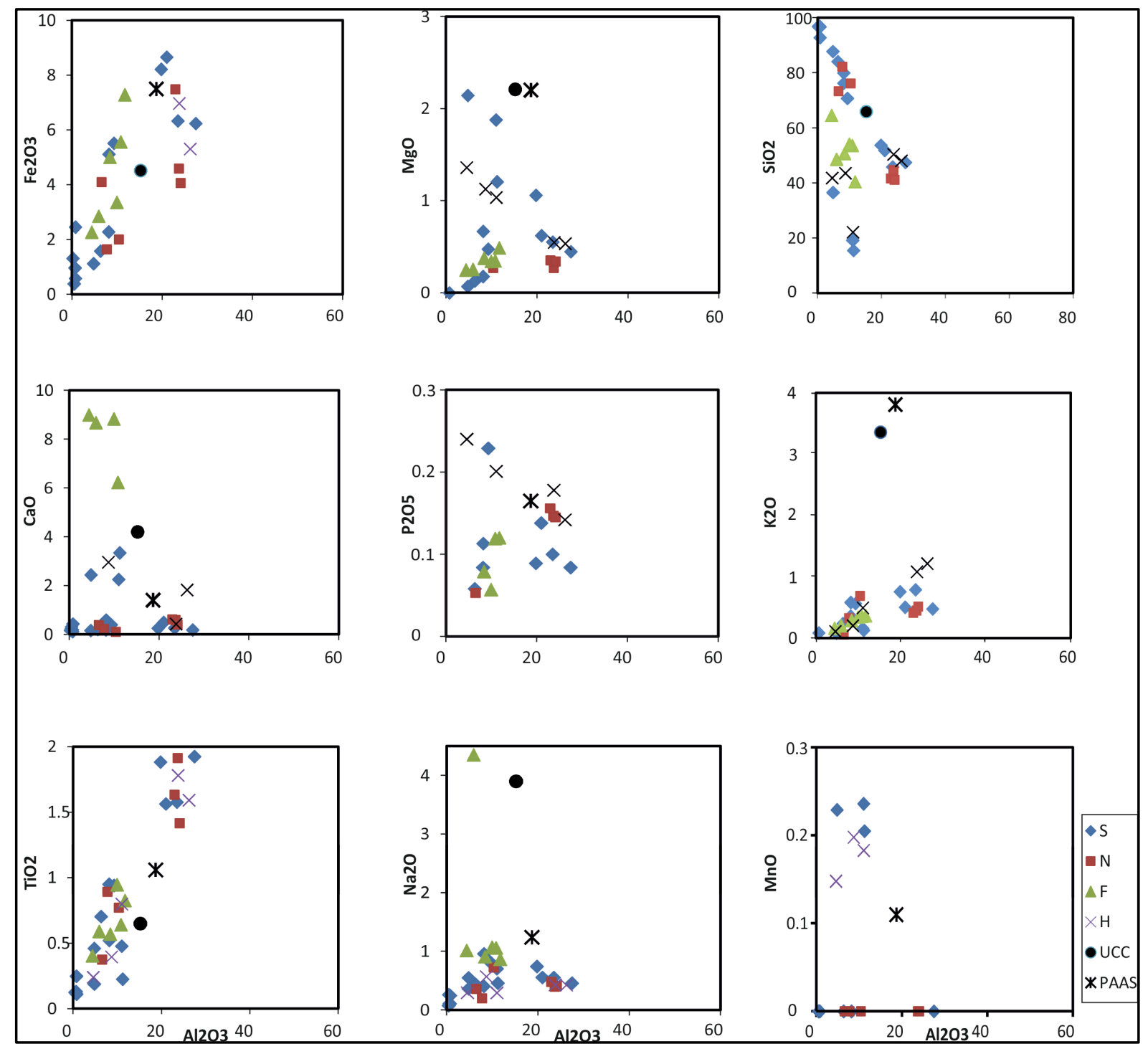

Figure 4. Major elements versus $\mathrm{Al}_{2} \mathrm{O}_{3}$ graph showing the distribution of samples from the Kazhdumi Formation. Average data of UCC and PAAS from Taylor and McLennan [32] are also plotted for comparison. 

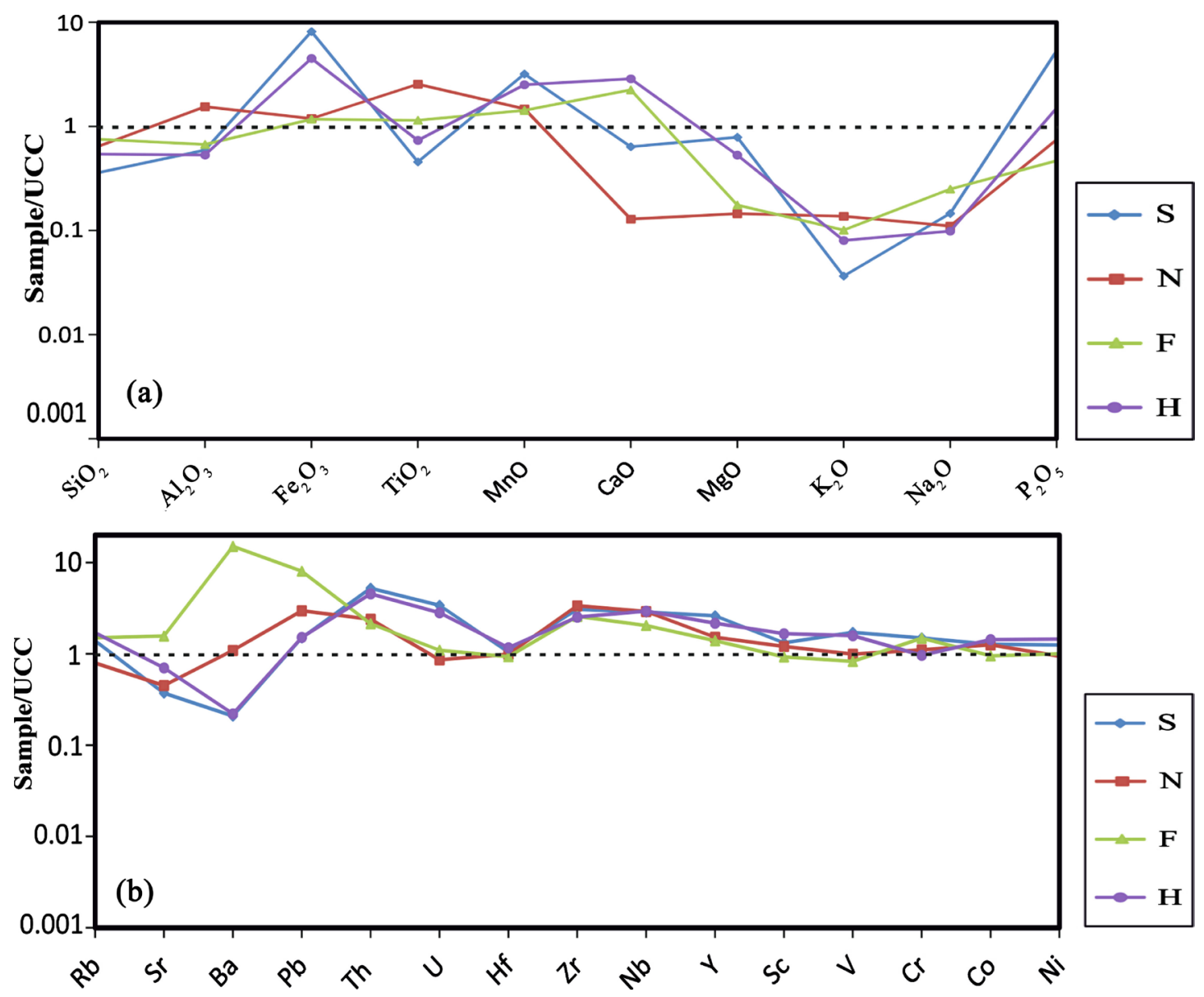

Figure 5. Spider plot of major and trace element compositions for the Kazhdumi samples normalized against UCC values. The UCC values are from Taylor and McLennan [32]. The trace elements are ordered with the large ion-lithophile elements (LILE: Rb-U), followed by high field strength elements (HFSE: Hf-Y) and the transition trace elements (TTE: Sc-Ni).

In comparison with UCC, the shale samples are low in $\mathrm{MgO}, \mathrm{CaO}, \mathrm{MnO}$ and high in $\mathrm{Al}_{2} \mathrm{O}_{3}$ and $\mathrm{TiO}_{2}$. $\mathrm{Al}$ and $\mathrm{Ti}$ are easily absorbed by clays and concentrate in the finer, more weathered materials [33]. In addition, XRD analysis of the shale samples reveals that they are associated with the mineral anatase $\left(\mathrm{TiO}_{2}\right)$. On average, the shale samples have lower $\mathrm{SiO}_{2}$ abundances relative to UCC therefore the observed variations are probably due to quartz dilution effect [31] [34]. In addition, sideritic sandstone samples are low in $\mathrm{SiO}_{2}$ and high in $\mathrm{Fe}_{2} \mathrm{O}_{3}$ due to siderite $\left(\mathrm{FeCO}_{3}\right)$ content base on XRD analysis.

\subsection{Trace Elements}

\subsubsection{Large-Ion Lithophile Elements (LILE): $\mathrm{Rb}, \mathrm{Sr}, \mathrm{Ba}$, Th and $\mathrm{U}$}

Compared with average upper continental crust (UCC) [32], analyzed samples at Soroosh, Nowrooz and Hendijan subsurface sections have relatively low concentrations in large ion lithophile elements (LILE), such as Ba and $\mathrm{Sr}$ (Figure 5(b)). The average abundances of $\mathrm{Ba}$ and $\mathrm{Sr}$ from Foroozan subsurface section are relatively high concentrations.

The general paucity of clay minerals in these sandstones from Kazhdumi Formation at Soroosh, Nowrooz and Hendijan subsurface sections probably influenced the depletions of these elements (Ba and Sr), as they may be often hosted as cations in the phyllosilicate mineral structures (e.g., Caracciolo et al., [35]). In Kazhdumi sandstones Th and $U$ show similar geochemical behavior due to their high positive correlation coefficient $(r=0.97 ; n=35)$.

\subsubsection{High Field-Strength Elements (HFSE): Hf, Zr, Nb and Y}

$\mathrm{Hf}, \mathrm{Zr}, \mathrm{Nb}$ and $\mathrm{Y}$ are preferentially partitioned into melts during crystallization and anatexis [36] [37], and as a 
result, these elements are enriched in felsic rather in mafic rocks [31]. Additionally, they are thought to reflect provenance compositions as a consequence of their immobile behavior [32].

In general, the concentrations of HFSE in our samples are relatively similar to UCC. The concentrations of some high field strength elements, such as $\mathrm{Zr}, \mathrm{Nb}$ and $\mathrm{Y}$, are higher in samples from Soroosh, Nowrooz, Foroozan and Hendijan subsurface sections compared with those of the UCC (Figure 5(b)).

Samples from the study area compared with the UCC are distinctly enriched in Zr (average 550 ppm). Zirconium is one of the famous heavy mineral in most of the sandstones, which can be found mostly in all of sedimentary environments [38]. In addition, this mineral is more stable during physical and chemical weathering [39]. Zirconium is generally considered to be the least mobile elements during chemical weathering. Significant amounts of $\mathrm{Zr}$ are typically fixed in resistant minerals such as zircon.

The strong positive correlations obtained for $\mathrm{TiO}_{2}$ with $\mathrm{Zr}(\mathrm{r}=0.82, \mathrm{r}=0.70, \mathrm{r}=0.88$ and $\mathrm{r}=0.96$ respectively for Soroosh, Nowrooz, Foroozan and Hendijan samples) and $\mathrm{Nb}(\mathrm{r}=0.97, \mathrm{r}=0.92, \mathrm{r}=0.78$ and $\mathrm{r}=0.62$ respectively for Soroosh, Nowrooz, Foroozan and Hendijan samples) suggest that their behavior is mainly controlled by the detrital heavy mineral fraction.

\subsubsection{Transition Trace Elements (TTE): $\mathrm{Sc}, \mathrm{V}, \mathrm{Cr}$, Co and Ni}

TTE in analyzed samples are quite similar to UCC (Figure 5(b)). Among TTE, Sc, V and Ni are correlated positively with $\mathrm{Al}_{2} \mathrm{O}_{3}$. The positive correlations obtained for $\mathrm{Al}_{2} \mathrm{O}_{3}$ with $\mathrm{Sc}(\mathrm{r}=0.92, \mathrm{r}=0.95, \mathrm{r}=0.94$ and $\mathrm{r}=$ 0.58), $\mathrm{V}(\mathrm{r}=0.99, \mathrm{r}=0.94, \mathrm{r}=0.82$ and $\mathrm{r}=0.52)$ and $\mathrm{Ni}(\mathrm{r}=0.88, \mathrm{r}=0.80, \mathrm{r}=0.99$ and $\mathrm{r}=0.94)$ indicates that their distribution is mainly controlled by phyllosilicate minerals ("r"s respectively for Soroosh, Nowrooz, Foroozan and Hendijan samples).

\section{Discussion}

\subsection{Nature of Source Rocks}

In order to determine the source of sediments using trace-elements (for example, Th, Co, Ni, Sc, Zr, Hf and Nb), it is necessary to ascertain that the element is relatively immobile in the sedimentary cycle [12] [40] [41].

Th abundances are higher in felsic than in mafic igneous source rocks and in their weathered products, whereas $\mathrm{Co}$, Sc and $\mathrm{Cr}$ are more concentrated in mafic than felsic igneous rocks and in their weathered products. Mafic and felsic source rocks differ significantly in the ratios such of $\mathrm{La} / \mathrm{Sc}, \mathrm{Th} / \mathrm{Sc}, \mathrm{La} / \mathrm{Co}, \mathrm{Th} / \mathrm{Co}$ and $\mathrm{Cr} / \mathrm{Th}$ and hence provide useful information about the provenance of sedimentary rocks (e.g., Cullers et al., [42]; Cullers, [43]; Cullers and Podkovyrov, [44]). In this study, $\mathrm{La} / \mathrm{Sc}, \mathrm{Th} / \mathrm{Sc}, \mathrm{La} / \mathrm{Co}, \mathrm{Th} / \mathrm{Co}$ and $\mathrm{Cr} / \mathrm{Th}$ values of the Late Lower Cretaceous (Albian) sandstones are more similar to values for sediments derived from felsic source rocks than to those for mafic source rocks, thus suggesting felsic source rocks (Table 1).

Floyd and Leveridge [45] stated that the elemental ratio of La/Th plotted versus the concentration of hafnium demonstrates the degree of recycling in sandstones and it also provides information about the provenance. A $\mathrm{La} / \mathrm{Th}$ versus Hf plot for the Albian sandstones at Soroosh, Nowrooz, Foroozan and Hendijan oil fields shows felsic source rocks, an intense recycling and sedimentary source and a passive margin tectonic setting for these sandstones (Figure 6).

Table 1. Range of elemental ratios from Late Lower Cretaceous (Albian) Kazhdumi Formation sandstones at Soroosh, Nowrooz, Foroozan and Hendijan oil fields compared to elemental ratios in sediments derived from felsic rocks, mafic rocks and in the Upper Continental Crust.

\begin{tabular}{cccccccc}
$\begin{array}{c}\text { Elemental } \\
\text { ratio }\end{array}$ & $\begin{array}{c}\text { Upper } \\
\text { continental crust }^{2}\end{array}$ & $\begin{array}{c}\text { Range of } \\
\text { sediment from } \\
\text { mafic sources }^{1}\end{array}$ & $\begin{array}{c}\text { Range of } \\
\text { sediment } \\
\text { from felsic } \\
\text { sources }^{1}\end{array}$ & $\begin{array}{c}\text { Range of } \\
\text { “Soroosh” } \\
\text { samples } \\
\mathbf{n}=\mathbf{1 8}\end{array}$ & $\begin{array}{c}\text { Range of } \\
\text { “Nowrooz” } \\
\text { samples } \\
\mathbf{n}=\mathbf{6}\end{array}$ & $\begin{array}{c}\text { Range of } \\
\text { "Foroozan” } \\
\text { samples } \\
\mathbf{n}=\mathbf{6}\end{array}$ & $\begin{array}{c}\text { Range of } \\
\text { “Hendijan” } \\
\text { samples } \\
\mathbf{n}=\mathbf{5}\end{array}$ \\
\hline $\mathbf{L a} / \mathbf{S c}$ & 2.21 & $0.43-0.86$ & $2.50-16.3$ & $1.9-8.1$ & $2.5-5.2$ & $2.8-3.8$ & $1.4-3.7$ \\
$\mathbf{T h} / \mathbf{S c}$ & 0.79 & $0.05-0.22$ & $0.84-20.5$ & $1-12.5$ & $1-4.3$ & $1.5-2.1$ & $0.9-6.3$ \\
$\mathbf{L a} / \mathbf{C o}$ & 1.76 & $0.14-0.38$ & $1.80-13.8$ & $1.3-3.9$ & $1.6-3.1$ & $2-3.1$ & $1.7-2.5$ \\
$\mathbf{T h} / \mathbf{C o}$ & 0.63 & $0.04-1.40$ & $0.67-19.4$ & $0.4-6.9$ & $0.9-1.8$ & $1.2-2$ & $0.8-4.2$ \\
$\mathbf{C r} / \mathbf{T h}$ & 7.76 & $25-500$ & $4.00-15.0$ & $0.4-140$ & $1.6-6$ & $4.7-11.2$ & $0.4-5.5$ \\
\hline
\end{tabular}

${ }^{1}$ Cullers [43]; Cullers and Podkovyrov [44]; Cullers et al. [42]. ${ }^{2}$ McLennan [40]; Taylor and McLennan [32]. 
$\mathrm{Th} / \mathrm{U}$ in sedimentary rocks is of interest, as weathering and recycling typically result in loss of $\mathrm{U}$, leading to an elevation in the $\mathrm{Th} / \mathrm{U}$ ratio. The $\mathrm{Th} / \mathrm{U}$ ratio in most upper crustal rocks is typically between 3.5 and 4 and $\mathrm{Th} / \mathrm{U}$ values higher than 4 may indicate intense weathering in source areas or sediment recycling [13]. Th/U ratios in the sandstones from Kazhdumi Formation range from 4.67 to 19.25, 6.11 to 19.30, 6.76 to 9.14 and 5.12 to 10.97 respectively for Soroosh, Nowrooz, Foroozan and Hendijan samples, indicating the derivation of these sandstones from recycling of the crust.

$\mathrm{Th} / \mathrm{Sc}$ ratio commonly reflects the average composition of the source rocks. Scandium and Th are transferred quantitatively from source to sediment; hence, the ratio is used to deduce the composition of the source rock [McLennan et al., 1993]. When Th/Sc is plotted on the diagram of $\mathrm{Zr} / \mathrm{Sc}-\mathrm{Th} / \mathrm{Sc}$ (Figure 7), the recycled source rocks for the sandstone samples from the Soroosh, Nowrooz and Foroozan subsurface section are further supported by their high $\mathrm{Zr} / \mathrm{Sc}$ ratio. Strongly enriched $\mathrm{Zr}$ in zircon can be easily recycled and Sc is present in labile phases. Therefore, the $\mathrm{Zr} / \mathrm{Sc}$ ratio is considered as one of the proxy to evaluate the presence or absence of recycling [13], but samples from Hendijan oil field fallow the trend of first order sediments and show a simple positive correlation between these ratios.

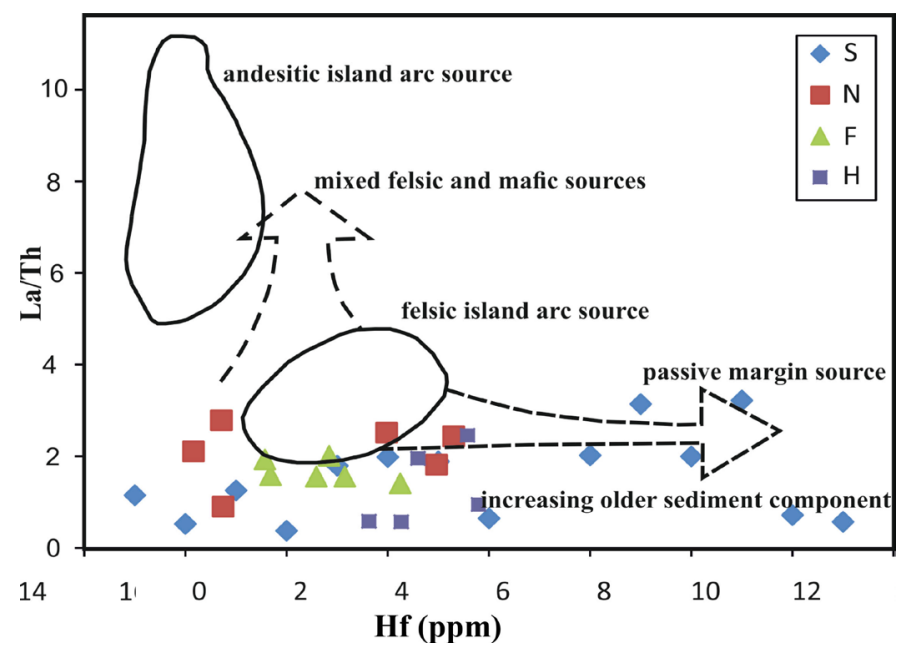

Figure 6. Source rock Hf-La/Th discrimination diagram for the discussion of the clastic sediments and their compositions [45] for Late Lower Cretaceous (Albian) Kazhdumi Formation sandstones at Soroosh, Nowrooz, Foroozan and Hendijan oil fields.

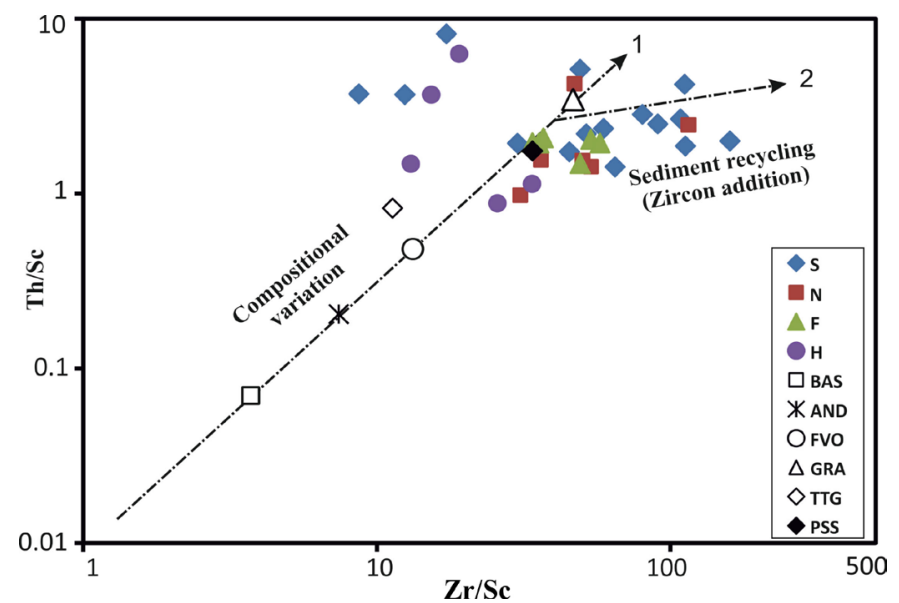

Figure 7. Th/Sc versus Zr/Sc diagram (after McLennan et al., [13]). Trend 1 represents sediments derived from igneous rocks and are less affected by sedimentary sorting and recycling. Trend 2 represents heavy mineral accumulation by sedimentary sorting and recycling. Most of the Kazhdumi Formation sandstones are enriched in zircon, due to sedimentary sorting and recycling. Legend: BAS = basalt; AND = andesite; FVO = felsic volcanic rocks; GRA = granite; TTG = tonalite-trondhjemite-granodiorite; PSS = Proterozoic sandstones (averages source rock composition from Condie, [46]). 
Felsic provenance for Kazhdumi samples, is further supported by the $\mathrm{TiO}_{2}$ versus Ni bivariate plot (Figure 8). Even though few samples plot outside the field assigned for felsic source. On a La/Sc versus Th/Co bivariate diagram (Figure 9), most of the samples plot near to the silicic rock provenance composition.

Furthermore, the V-Ni-Th*10 (Figure 10) ternary diagram also suggests that the Kazhdumi sandstones were derived from felsic source rocks.

The post-Archean pelites have low concentrations of mafic elements, particularly Ni and Cr, when compared to Archean pelites [13]. The reason for the high concentrations of $\mathrm{Ni}$ and $\mathrm{Cr}$ in the Archean pelites is due to the deficiency of ultra-mafic rocks in the post-Archean Period [32]. The Kazhdumi sandstones plot in the postArchean field (Figure 11) suggest that the felsic component was dominant in the source area of the Kazhdumi Formation.

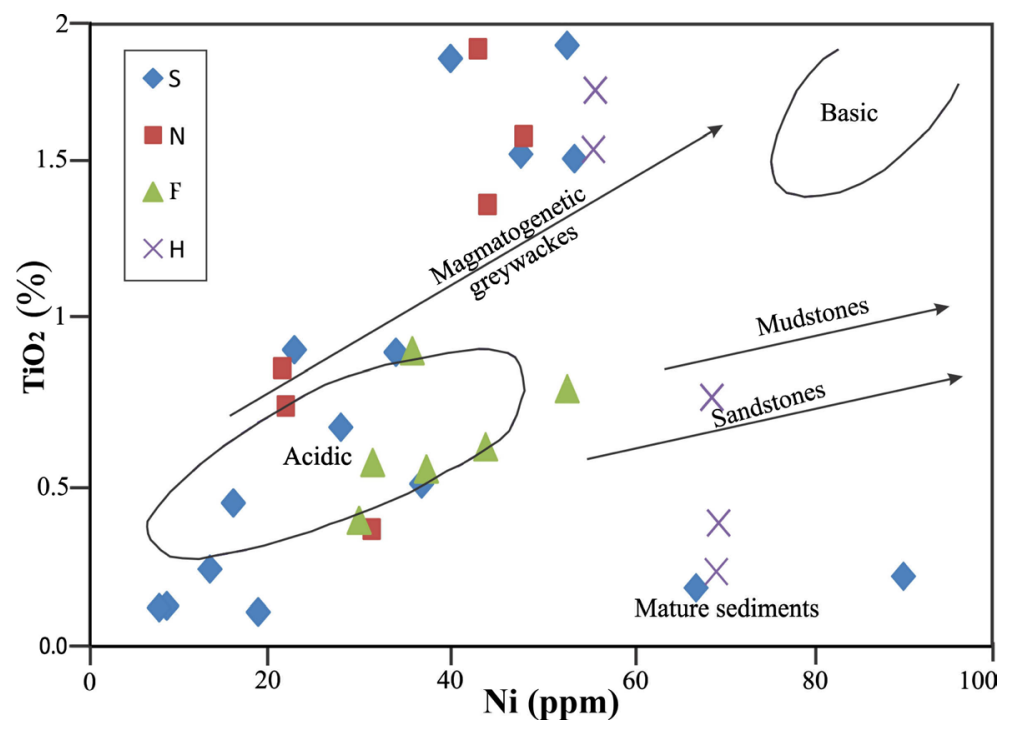

Figure 8. $\mathrm{TiO}_{2}$ versus Ni bivariate plot for the Kazhdumi sandstones (fields after Floyd et al., [47]). Majority of the samples plot near the acidic source field.

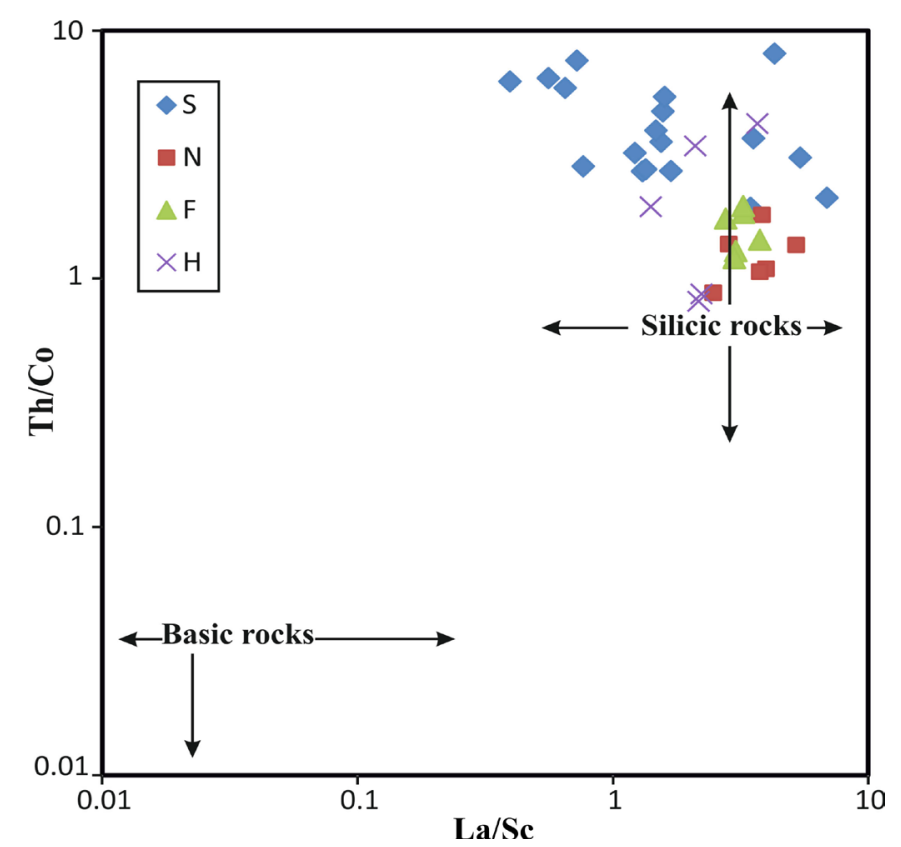

Figure 9. Th/Co versus La/Sc plot (after Cullers, [48]). Kazhdumi sandstones plot near the silicic source, whereas loose sand samples are low in $\mathrm{La} / \mathrm{Sc}$ ratio. 


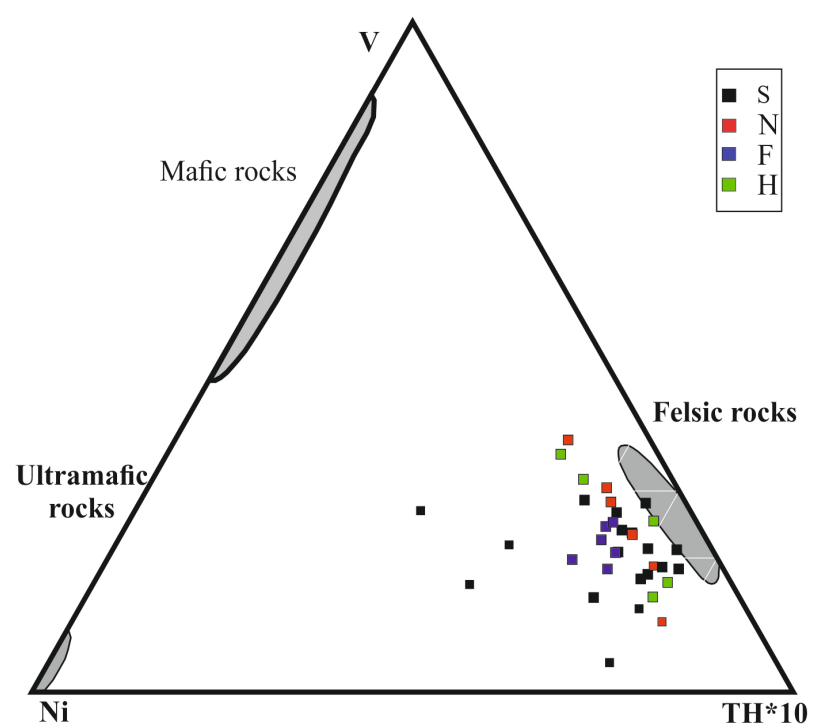

Figure 10. V-Ni-Th*10 triangle diagram (after Bracciali et al., [49]). Shaded area represents composition of the felsic, mafic, and ultramafic rocks. The Kazhdumi sandstones plot near felsic source rocks. Loose sand samples with high Ni content are shifting toward the Ni corner.

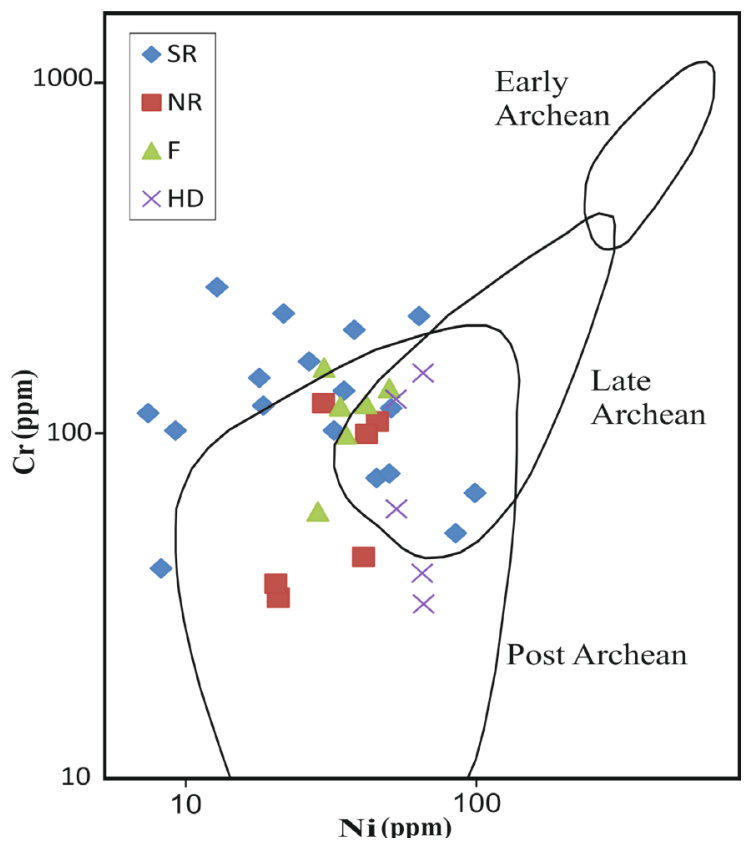

Figure 11. Ni-Cr bivariate plot for the samples from the Kazhdumi Formation [13].

\subsection{Implication for Tectonic Setting}

Trace elements are generally thought to be quantitatively transported into clastic sedimentary rocks after weathering, and thus, they may reflect the signature of parent materials and these elements can be used in sedimentary rocks to determine their provenance and tectonic setting (e.g., McLennan et al. [13]; Bahlburg [50]; Burnett and Quirk [51]; Zimmermann and Bahlburg [52]; Cingolani et al. [53]; Li et al. [54]).

The negative Sr-anomaly, which is suggesting the older recycled environments/passive margin setting, is common in most of the sandstone samples at Kazhdumi subsurface sections (Figure 5(b)). Positive Zr anomaly at Samples suggest a slight influence of mature sedimentary detritus (zircon) of a passive continental margin (e.g., Mader and Neubauer [55]). 
Furthermore, we used the triangle diagram Th-Sc-Zr/10 and discrimination diagram of La/Sc versus Ti/Zr [12], to understand the tectonic setting of studied samples based on these plots. Most of the samples cluster within or close to the passive continental margin field (Figure 12); therefore, they may have been derived from such tectonic setting, although some samples plot in continental island arc. This interpretation must be made cautiously, because specific tectonic settings do not necessarily produce rocks with unique geochemical signatures [50].

\subsection{Source Area Weathering}

The intensity and duration of weathering in clastic sediments can be evaluated by examining the relationships among alkali and alkaline rare earth elements [56] [57]. Nesbitt and Young [58] defined the Chemical Index of Alteration (CIA) formula to evaluate the degree of chemical weathering:

$$
\mathrm{CIA}=\left[\mathrm{Al}_{2} \mathrm{O}_{3} /\left(\mathrm{Al}_{2} \mathrm{O}_{3}+\mathrm{CaO} *+\mathrm{Na}_{2} \mathrm{O}+\mathrm{K}_{2} \mathrm{O}\right)\right] \times 100 .
$$

where the oxides are expressed as molar proportions and $\mathrm{CaO} *$ represents the $\mathrm{Ca}$ in silicate fractions only. Another good measure to calculate the degree of chemical weathering is Plagioclase Index of Alteration (PIA; Fedo et al., [59]), which can be calculated by the following equation (molecular proportions):

$$
\mathrm{PIA}=\left[\left(\mathrm{Al}_{2} \mathrm{O}_{3}-\mathrm{K}_{2} \mathrm{O}\right) /\left(\mathrm{Al}_{2} \mathrm{O}_{3}+\mathrm{CaO}+\mathrm{Na}_{2} \mathrm{O}-\mathrm{K}_{2} \mathrm{O}\right)\right] \times 100 .
$$

Above mentioned indexes of alteration may not help us to obtain acceptable results specially in samples with high fluctuation in calcium contents [43]. So that this is observed in most of samples in this study. However, this alteration index doesn't give certain results because of high carbonate contents. Accordingly, Cullers [43] defined the Chemical Index of Weathering (CIW) formula to calculate the degree of chemical weathering for the sandstones with high $\mathrm{CaO}$ content, which can be calculated by the following equation:

$$
\mathrm{CIW}=\left[\mathrm{Al}_{2} \mathrm{O}_{3} /\left(\mathrm{Al}_{2} \mathrm{O}_{3}+\mathrm{Na}_{2} \mathrm{O}\right)\right] \times 100
$$

where the oxides are expressed as molar proportion. CIW is variable form 50 in non-weathered sediments to 100 in intense weathered sediments. The high CIW values in the Soroosh, Nowrooz, Foroozan and Hendijan samples (90.8, 96.7, 83.9 and 96.4 respectively) indicate a moderate to intense weathering of first cycle sediments, or it may alternatively reflect recycling under semi-arid to semi-humid climate conditions. CIW values also signify a dominant felsic source and sediment recycling processes [28].

\subsection{Probable Source Rocks (Regional Perspective)}

The study area was a tectonically passive carbonate platform from the Late Permian to about Late Cretaceous [21]. The Albian to Cenomanian is evident by shallow-marine carbonate and intra-shelf basins [60] [61]. Eus-
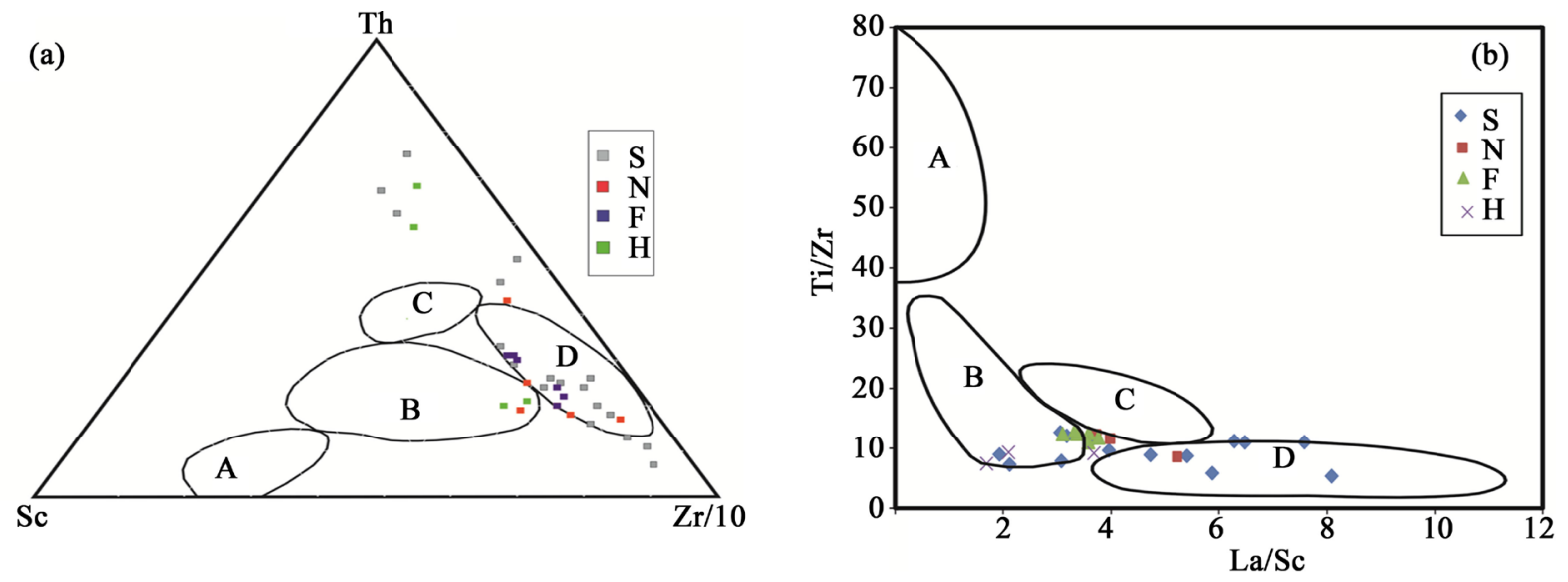

Figure 12. Trace element composition of the sandstones from Kazhdumi Formation on the triangle and bivariate tectonic setting discrimination diagrams of Bhatia and Crook [12]. See text for details. Legend: A = oceanic island arc; B = continental island arc; $\mathrm{C}=$ active continental margin; $\mathrm{D}$ = passive continental margin. 
tatic sea-level fluctuations and local differential subsidence controlled sediment deposition during the mentioned interval [61].

Following a period of subaerial exposure in the early-middle Aptian, which lasted for approximately $1.5 \mathrm{MM}$ yrs [62], the Albian clastics comprised the initial deposits of a mid-Cretaceous transgressive cycle in eastern Arabia. Eustatic sea-level during this time was relatively low [63]. The Kazhdumi/Nahr Umr/Burgan Formations represent a major of terrigenous clastic sediments from the Arabian Shield to the west and from the Interior Homocline area of Central Saudi Arabia [Early Paleozoic clastic rocks), which prograded eastwards onto the Aptian carbonate platform. The pre-Wasia unconformity surface was exposed, and the uplifted Hail Rutbah Arch was deeply eroded; recycled sediments were transported and deposited as the Wasia/Kazhdumi clastics [64].

A thick wedge of alluvial-plain and lower coastal plain sandstones comprise the prolific reservoir facies of the Kazhdumi/Nahr Umr/Burgan sandstones of Iran offshore, South Iraq, Kuwait and extend to NE Soudi Arabia [65]. This setting conforms to a classic ramp model, which terrestrial and near-shore marine, coarse to medium grained sandstones, grading into a very large area offshore of shallow water shales, which was a much as 500 $\mathrm{km}$ wide [62] [66]. The fine grained clastics grade eastwards into impure carbonates in the extreme northern part of the UAE, and marginal to the NW Oman Mountains [62]. The Nahr Umr and its equivalent is not a starved basin but a marine-shelf where the shallow setting led to continued reworking of fine grained clastic sediments during storms, with the development of multiple local unconformities of short duration [21].

The Albian clastics in South Iraq and Kuwait comprise the delta-front of the Saudi Arabia succession. Towards Iran, clastics intercalated with carbonates represent increasingly marine delta-front conditions. In Bahrain and western Qatar, the Nahr Umr consists largely of sands and sandstones, but in eastern Qatar it contains many shale bands, with marly shales and glauconitic sands near the top. The proportion of sand diminishes toward Abu Dhabi. In northern United Arab Emirates and Oman, argillaceous limestone, calcareous shale and marl were deposited in a shallow, mixed shelf environment [21] (Figure 13).

Considering paleogeographic data during the Late Lower Cretaceous (Albian) and geochemical studies, the source of sandstones for the Kazhdumi Formation might be assigned to uplifted shoulders of a rifted basin (Neo-Tethys) in its post-rift stage (Arabian basement), but the effect of recycling due to tectonic events on these sandstones might be considered (Figure 14). Such provenance interpretation has to be considered with caution because the role of sedimentary environment and diagenesis.

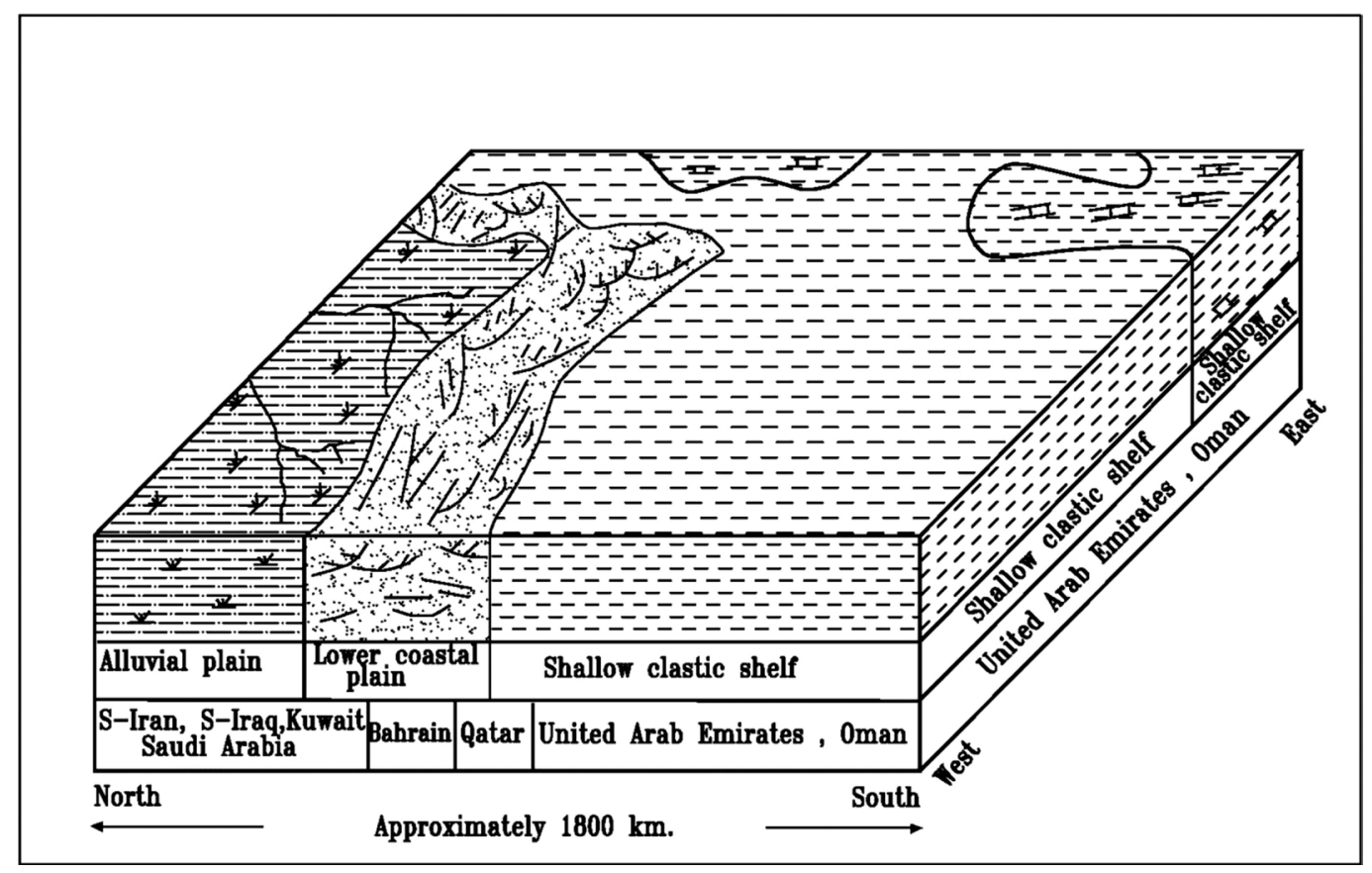

Figure 13. Paleogeographic model of the Albian clastics in the western Persian Gulf (modified after Alsharhan and Nairn, [66]; Murris, [65]). 


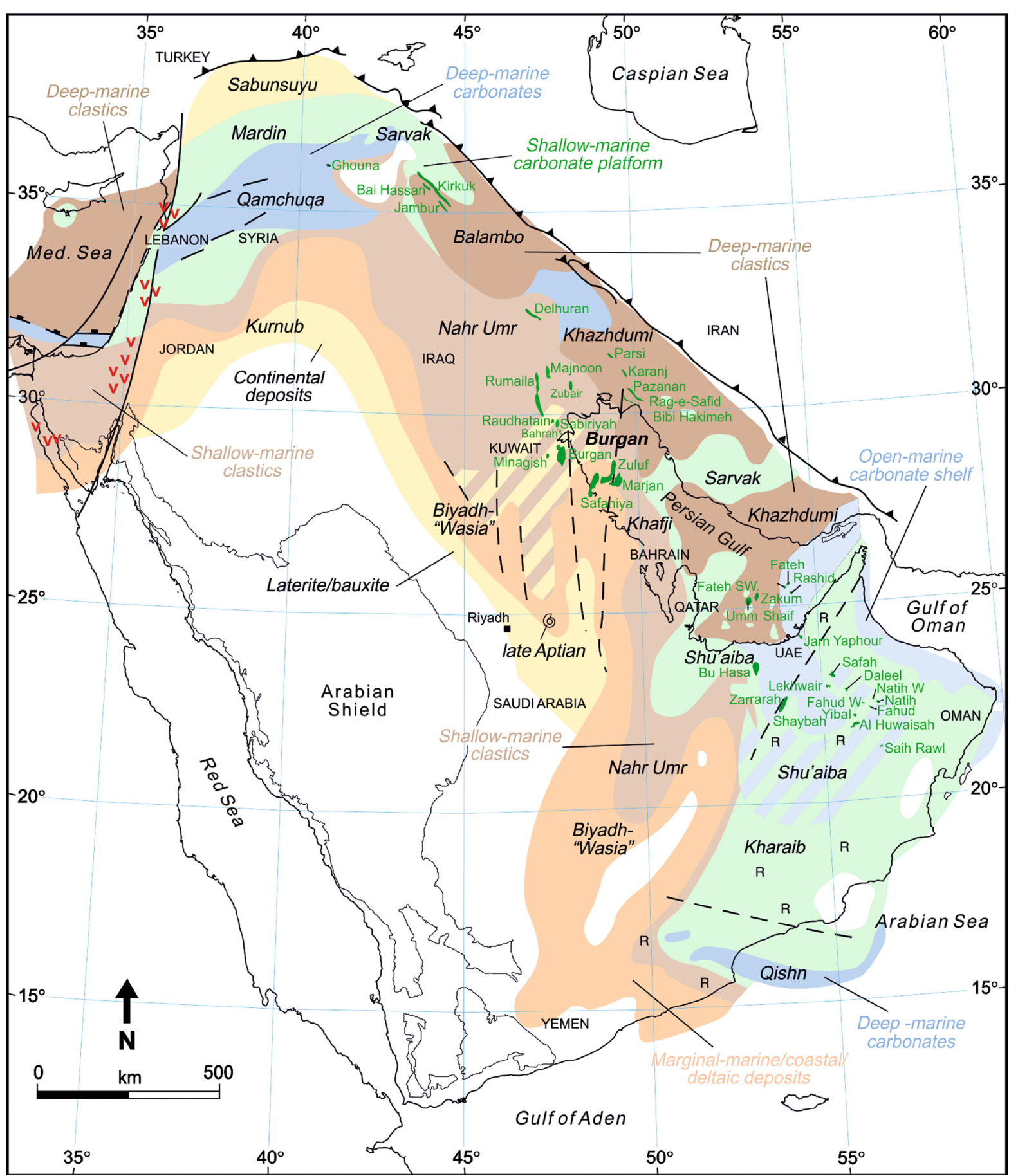

Figure 14. Paleofacies of the late Early Cretaceous spanning deposition of the Shuaiba, Biyadh, Nahr Umr, Burgan, and Kazhdumi formations, and their regional equivalents [67].

\section{Conclusions}

The provenance of the Late Lower Cretaceous (Albian) Kazhdumi Formation sandstones in offshore of SW Iran has been assessed using geochemical (major and trace elements) studies. The results are generally in agreement in term of source rocks, tectonic setting and paleoweathering. The geochemical characteristics suggest these sandstones are predominantly derived from a felsic source, which are located in the Arabian basement. This approach has revealed that the sandstones of Kazhdumi Formation were primarily derived from sources typical of 
a cratonic interior. Also, the provenance characteristics based on geochemical methods suggest that the Kazhdumi sandstones were deposited on a passive margin that received large amounts of mature detritus from the source areas. Moreover, the data indicate a possible increase in weathering intensity in the source area with a long distance transport, possibly over the Arabian shield that might have supplied sands to the depositional basin along the passive marginal coast of the Neo-Tethys.

Similar this study could be done in Arash and Esfandiar oil fields, which are situated in southern part of interest area, in order to expand and improve models for the evolution of the Late Lower Cretaceous (Albian) siliciclastic rocks of the Middle East.

\section{Acknowledgements}

Authors thank the R\&T department and Geology section of Iranian offshore Oil Company for their supporting.

\section{References}

[1] Khan, A. and Shahnawaz, A. (2013) Petrography and Provenance of Early Triassic Pachmarhi Formation Sandstones, Satpura Gondwana Basin, Madhya Pradesh, Central India. Open Journal of Geology, 3, 83-93.

[2] Armstrong-Altrin, J.S., Lee, Y.I., Verma, S.P. and Ramasamy, S. (2004) Geochemistry of Sandstones from the Upper Miocene Kudankulam Formation, southern India: Implication for Provenance, Weathering and Tectonic Setting. Journal of Sedimentary Research, 74, 285-297. http://dx.doi.org/10.1306/082803740285

[3] Dostal, J. and Keppie, J.D. (2009) Geochemistry of Low-Grade Clastic Rocks in the Acatlán Complex of Southern Mexico: Evidence for Local Provenance in Felsic Intermediate Igneous Rocks. Sedimentary Geology, 222, 241-253. http://dx.doi.org/10.1016/j.sedgeo.2009.09.011

[4] Jafarzadeh, M. and Hosseini-Barzi, M. (2008) Petrography and Geochemistry of Ahwaz Sandstone Member of Asmari Formation, Zagros, Iran: Implications on Provenance and Tectonic Setting. Revista Mexicana de Ciencias Geológicas, 25, 247-260.

[5] Umazano, A.M., Bellosi, E.S., Visconti, G., Jalfin, A.G. and Melchor, R.N. (2009) Sedimentary Record of a Late Cretaceous Volcanic Arc in Central Patagonia: Petrography, Geochemistry and Provenance of Fluvial Volcaniclastic Deposits of the Bajo Barreal Formation, San Jorge Basin, Argentina. Cretaceous Research, 30, 749-766. http://dx.doi.org/10.1016/j.cretres.2008.12.015

[6] Absar, N., Raza, M., Roy, M., Naqvi, S.M. and Roy, A.K. (2009) Composition and Weathering Conditions of Paleoproterozoic Upper Crust of Bundelkhand Craton, Central India: Records from Geochemistry of Clastic Sediments of 1.9 Ga Gwalior Group. Precambrian Research, 168, 313-329. http://dx.doi.org/10.1016/j.precamres.2008.11.001

[7] Chakrabarti, G., Shome, D., Bauluz, B. and Sinha, S. (2009) Provenance and Weathering History of Mesoproterozoic Clastic Sedimentary Rocks from the Basal Gulcheru Formation, Cuddapah Basin, India. Journal of the Geological Society of India, 74, 119-130. http://dx.doi.org/10.1007/s12594-009-0096-7

[8] Hossain, H.M.Z., Roser, B.P. and Kimura, J.I. (2010) Petrography and Whole-Rock Geochemistry of the Tertiary Sylhet Succession, Northeastern Bengal Basin, Bangladesh: Provenance and Source Area Weathering. Sedimentary Geology, 228, 171-183. http://dx.doi.org/10.1016/j.sedgeo.2010.04.009

[9] De Araújo, C.E.G., Pinéo, T.R.G., Caby, R., Costa, F.G., Cavalcante, J.C., Vasconcelos, A.M. and Rodrigues, J.B. (2010) Provenance of the Novo Oriente Group, Southwestern Ceará Central Domain, Borborema Province (NE-Brazil): A Dismembered Segment of a Magma-Poor Passive Margin or a Restricted Riftrelated Basin? Gondwana Research, 18, 497-513. http://dx.doi.org/10.1016/j.gr.2010.02.001

[10] Ranjan, N. and Banerjee, D.M. (2009) Central Himalayan Crystallines as the Primary Source for the Sandstone-Mudstone suites of the Siwalik Group: New Geochemical Evidence. Gondwana Research, 16, 687-696. http://dx.doi.org/10.1016/j.gr.2009.07.005

[11] Zimmermann, U. and Spalletti, L.A. (2009) Provenance of the Lower Paleozoic Balcarce Formation (Tandilia System, Buenos Aires Province, Argentina): Implications for Paleogeographic Reconstructions of SW Gondwana. Sedimentary Geology, 219, 7-23. http://dx.doi.org/10.1016/j.sedgeo.2009.02.002

[12] Bhatia, M.R. and Crook, K.W. (1986) Trace Element Characteristics of Greywackes and Tectonic Setting Discrimination of Sedimentary Basins. Contributions to Mineralogy and Petrology, 92, 181-193. http://dx.doi.org/10.1007/BF00375292

[13] McLennan, S.M., Hemming, S., McDaniel, D.K. and Hanson, G.N. (1993) Geochemical Approaches to Sedimentation, Provenance and Tectonics. In: Johnsson, M.J. and Basu, A., Eds., Processes Controlling the Composition of Clastic Sediments: Geological Society of America, Special Papers, 285, 21-40. http://dx.doi.org/10.1130/SPE284-p21

[14] Armstrong-Altrin, J.S. (2009) Provenance of Sands from Cazones, Acapulco, and Bahia Kino Beaches, Mexico. Mex- 
ican Geosciences Journal, 26, 764-782.

[15] Vaziri-Moghaddam, H., Seyrafian, A., Taheri, A. and Motiei, H. (2010) Oligocene-Miocene Ramp System (Asmari Formation) in the NW of the Zagros Basin, Iran: Microfacies, Paleoenvironment and Depositional Sequence. Revista Mexicana de Ciencias Geológicas, 27, 56-71.

[16] Kavoosi, M.A., Lasemi, Y., Sherkati, S. and Moussavi-Harami, R. (2009) Facies Analysis and Depositional Sequences of the Upper Jurassic Mozduran Formation, a Carbonate Reservoir in the Kopet Dagh Basin, NE Iran. Journal of Petroleum Geology, 32, 235-259. http://dx.doi.org/10.1111/j.1747-5457.2009.00446.x

[17] Alsharhan, A.S. (1991) Sedimentological Interpretation of the Albian Nahr Umr Formation in the United Arab Emirates. Sedimentary Geology, 73, 317-327. http://dx.doi.org/10.1016/0037-0738(91)90091-Q

[18] Al-Eidan, A.J., Wethington, W.B. and Davies, R.B. (2001) Upper Burgan Reservoir Distribution, Northern Kuwait: Impact on Reservoir Development. Geoarabia, 6, 179-208.

[19] Strohmenger, C.J., Patterson, P.E., Al-Sahlan, G., Mitchell, J.C., Feldman, H.R., Demko, T.M., Wellner, W., Lehmann, P.J., McCrimmon, G.G., Broomhall, R.W. and Al-Ajmi, N. (2006) Sequence Stratigraphy and Reservoir Architecture of the Burgan and Mauddud Formations (Lower Cretaceous), Kuwait. In: Harris, P.M. and Weber, L.J., Eds., Giant Hydrocarbon Reservoirs of the World: From Rocks to Reservoir Characterization and Modeling. AAPG Memoir 88/SEPM Special Publication, 213-245.

[20] Van Buchem, F.S.P., Baghbani, D., Bulot, L.G., Caron, M., Gaumet, F., Hosseini, S.A., Keyvani, F., Schroeder, R., Swennen, R., Vedrenne, V. and Vincent, B. (2010) Barremian-Lower Albian Sequence-Stratigraphy of Southwest Iran (Gadvan, Dariyan and Kazhdumi Formations) and Its Comparison with Oman, Qatar and the United Arab Emirates. GeoArabia Special Publication 4, 2, 503-548.

[21] Alsharhan, A.S. (1994) Albian Clastics in the Western Arabian Gulf Region: A Sedimentological and PetroleumGeological Interpretation. Journal of Petroleum Geology, 17, 279-300.

[22] Van Bellen, R.C., Dunnington, H.V., Wetzel, R. and Morton, D.M. (1959) Iraq. Lexique Stratigraphique International III, Asie; Fasc. 10 a. Geol. Congr. Comm. Stratigr., Centre Nat. Recherche, Paris, 333 p.

[23] Owen, R.M.S. and Nasr, S.N. (1958) Stratigraphy of the Kuwait-Basra Area. Habitat of Oil, American Association Petroleum Geologist Memoir 1, 1252-1278.

[24] Al-Fares, A.A., Bouman, M. and Jeans, P. (1998) A New Look at the Middle to Lower Cretaceous Stratigraphy, Offshore Kuwait. GeoArabia: Middle East Petroleum Geosciences, 3, 543-560.

[25] Scott, R.W., Frost, S.H. and Shaffer, B.L. (1988) Early Cretaceous Sea-Level Curves, Gulf Coast and Southern Arabia. Sea-Level Changes-An Integrated Approach, Special Publication 42, Society of Economic Paleontologists and Mineralogists, 275-284.

[26] Mashhadi, Z.S. and Rabbani, A.R. (2015) Organic Geochemistry of Crude Oils and Cretaceous Source Rocks in the Iranian Sector of the Persian Gulf. An Oil-Oil and Oil-Source Rocks Correlation Study. International Journal of Coal Geology, 146, 118-144. http://dx.doi.org/10.1016/j.coal.2015.05.003

[27] Folk, R.L. (1980) Petrology of Sedimentary Rocks. Hemphill Press, Austin, 182 p.

[28] Innocent Ejeh, O., Anthony Akpoborie, I. and Israel Etobro, A.A. (2015) Heavy Minerals and Geochemical Characteristics of Sandstones as Indices of Provenance and Source Area Tectonics of the Ogwashi-Asaba Formation, Niger Delta Basin. Open Journal of Geology, 5, 562-576.

[29] Cardenas, A., Girty, G.H., Hanson, A.D. and Lahren, M.M. (1996) Assessing Differences in Composition between Low Metamorphic Grade Mudstones and High-Grade Schists Using Log Ratio Techniques. The Journal of Geology, 104, 279-293. http://dx.doi.org/10.1086/629825

[30] Madhavaraju, J. and Lee, Y.I. (2010) Influence of Deccan Volcanism in the Sedimentary Rocks of Late MaastrichtianDanian Age of Cauvery Basin Southeastern India: Constraints from Geochemistry. Current Science, 98, 528-537.

[31] Bauluz, B., Mayayo, M.J., Fernandez-Nieto, C. and Gonzalez-Lopez, J.M. (2000) Geochemistry of Precambrian and Paleozoic Siliciclastic Rocks from the Iberian Range (NE Spain): Implications for Source-Area Weathering, Sorting, Provenance, and Tectonic Setting. Chemical Geology, 168, 135-150. http://dx.doi.org/10.1016/S0009-2541(00)00192-3

[32] Taylor, S.R. and McLennan, S.M. (1985) The Continental Crust: Its Composition and Evolution. Scientific Publications, Oxford, 312 p.

[33] Das, B.K., AL-Mikhlafi, A.S. and Kaur, P. (2006) Geochemistry of Mansar Lake Sediments, Jammu, India: Implication for Source-Area Weathering, Provenance, and Tectonic Setting. Journal of Asian Earth Sciences, 26, 649-668. http://dx.doi.org/10.1016/j.jseaes.2005.01.005

[34] Dokuz, A. and Tanyolu, E. (2006) Geochemical Constraints on the Provenance, Mineral Sorting and Subaerial Weathering of Lower Jurassic and Upper Cretaceous Clastic Rocks of the Eastern Pontides, Yusufeli (Artvin), NE Turkey. 
Turkish Journal of Earth Sciences, 15, 181-209.

[35] Caracciolo, L., Le Pera, E., Muto, F. and Perri, F. (2009) Sandstone Petrology and Mudstone Geochemistry of the Peruc-Koryacany Formation (Bohemian Cretaceous Basin, Czech Republic). International Geology Review.

[36] Feng, R. and Kerrich, R. (1990) Geochemistry of Fine Grained Clastic Sediments in the Archaean Abitibi Greenstone Belt, Canada: Implications for Provenance and Tectonic Setting. Geochimica et Cosmochimica Acta, 54, 1061-1081. http://dx.doi.org/10.1016/0016-7037(90)90439-R

[37] Torres-Alvarado, I.S., Verma, S.P., Palacios-Berruete, H., Guevara, M. and González-Castillo, O.Y. (2003) DC_BASE: A Database System to Manage Nernst Distribution Coefficients and Its Application to Partial Melting Modeling. Computers \& Geosciences, 29, 1191-1198. http://dx.doi.org/10.1016/S0098-3004(03)00132-8

[38] Mange, M. and Otvos, E.G. (2005) Gulf Coastal Plain Evolution in West Louisiana: Heavy Mineral Provenance and Pleistocene Alluvial Chronology. Sedimentary Geology, 182, 29-57. http://dx.doi.org/10.1016/j.sedgeo.2005.07.015

[39] Morton, A.C. and Hallsworth, C.R. (2007) Stability of Detrital Heavy Minerals during Burial Diagenesis. In: Mange, M.A. and Wright, D.T., Eds., Heavy Minerals in Use. Developments in Sedimentology, 58, 215-245. http://dx.doi.org/10.1016/S0070-4571(07)58007-6

[40] McLennan, S.M. (2001) Relationships between the Trace Element Composition of Sedimentary Rocks and Upper Continental Crust. Geochemistry, Geophysics, Geosystems (G3), 2, 1021.

[41] Shao, L., Stettegger, K. and Garbe-Schoenberg, C.D. (2001) Sandstone Petrology and Geochemistry of the Turpan Basin (NW China): Implications for the Tectonic Evolution of a Continental Basin. Journal of Sedimentary Research, 71, 37-49. http://dx.doi.org/10.1306/041800710037

[42] Cullers, R.L., Basu, A. and Suttner, L.J. (1988) Geochemical Signature of Provenance in Sand-Size Material in Soils and Stream Sediments near the Tobacco Root Batholith, Montana, U.S.A. Chemical Geology, 70, 335-348. http://dx.doi.org/10.1016/0009-2541(88)90123-4

[43] Cullers, R.L. (2000) The Geochemistry of Shales, Siltstones and Sandstones of Pennsylvanian-Permian Age, Colorado, USA: Implications for Provenance and Metamorphic Studies. Lithos, 51, 181-203. http://dx.doi.org/10.1016/S0024-4937(99)00063-8

[44] Cullers, R.L. and Podkovyrov, V.N. (2000) Geochemistry of the Mesoproterozoic Lakhanda Shales in Southeastern Yakutia, Russia: Implications for Mineralogical and Provenance Control, and Recycling. Precambrian Research, 104, 77-93. http://dx.doi.org/10.1016/S0301-9268(00)00090-5

[45] Floyd, P.A. and Leveridge, B.E. (1987) Tectonic Environment of the Devonian Gramscatho Basin, South Cornwall: Framework Mode and Geochemical Evidence from Turbidite Sandstones. Journal of Geological Society of London, 144, 531-542. http://dx.doi.org/10.1144/gsigs.144.4.0531

[46] Condie, K.C. (1993) Chemical Composition and Evolution of the Upper Continental Crust: Contrasting Results from Surface Samples and Shales. Chemical Geology, 104, 1-37. http://dx.doi.org/10.1016/0009-2541(93)90140-E

[47] Floyd, P.A., Winchester, J.A. and Park, R.G. (1989) Geochemistry and Tectonic Setting of Lewisian Clastic Metasediments from the Early Proterozoic Loch Maree Group of Gairloch, N.W. Scotland. Precambrian Research, 45, 203214. http://dx.doi.org/10.1016/0301-9268(89)90040-5

[48] Cullers, R.L. (2002) Implications of Elemental Concentrations for Provenance, Redox Conditions, and Metamorphic Studies of Shales and Limestones near Pueblo, CO, USA. Chemical Geology, 191, 305-327. http://dx.doi.org/10.1016/S0009-2541(02)00133-X

[49] Bracciali, L., Marroni, M., Pandolfi, L. and Rocchi, S. (2007) Geochemistry and Petrography of Western Tethys Cretaceous Sedimentary Covers (Corsica and Northern Apennines): From Source Areas to Configuration of Margins. Geological Society of American Special Papers, 420, 73-93. http://dx.doi.org/10.1130/2006.2420(06)

[50] Bahlburg, H. (1998) The Geochemistry and Provenance of Ordovician Turbidites in the Argentine Puna. Geological Society of London, Special Publication, 142, 127-142. http://dx.doi.org/10.1144/gsl.sp.1998.142.01.07

[51] Burnett, D.J. and Quirk, D.G. (2001) Turbidite Provenance in the Lower Paleozoic Manx Group, Isle of Man; Implications for the Tectonic Setting of Eastern Avalonia. Journal of Geological Society of London, 158, 913-924. http://dx.doi.org/10.1144/0016-764900-205

[52] Zimmermann, U. and Bahlburg, H. (2003) Provenance Analysis and Tectonic Setting of the Ordovician Clastic Deposits in the Southern Puna Basin, NW Argentina. Sedimentology, 50, 1079-1104. http://dx.doi.org/10.1046/j.1365-3091.2003.00595.x

[53] Cingolani, C.A., Manassero, M. and Abre, P. (2003) Composition, Provenance, and Tectonic Setting of Ordovician Siliciclastic Rocks in the San Rafael Block: Southern Extension of the Precordillera Crustal Fragment, Argentina. Journal of South American Earth Sciences, 16, 91-106. http://dx.doi.org/10.1016/S0895-9811(03)00021-X

[54] Li, Q., Liu, S., Han, B., Zhang, J. and Chu, Z. (2005) Geochemistry of Metasedimentary Rocks of the Proterozoic 
Xingxingxia Complex: Implications for Provenance and Tectonic Setting of the Eastern Segment of the Central Tianshan Tectonic Zone, Northwestern China. Canadian Journal of Earth Science, 42, 287-306. http://dx.doi.org/10.1139/e05-011

[55] Mader, D. and Neubauer, F. (2004) Provenance of Paleozoic Sandstones from the Carnic Alps (Austria): Petrographic and Geochemical Indicators. International Journal of Earth Sciences, 93, 262-281. http://dx.doi.org/10.1007/s00531-004-0391-x

[56] Nesbitt, H.W. and Young, G.M. (1996) Petrogenesis of Sediments in the Absence of Chemical Weathering: Effects of Abrasion and Sorting on Bulk Composition and Mineralogy. Sedimentology, 43, 341-358. http://dx.doi.org/10.1046/j.1365-3091.1996.d01-12.x

[57] Nesbitt, H.W., Fedo, C.M. and Young, G.M. (1997) Quartz and Feldspar Stability, Steady and Non-Steady State Weathering and Petrogenesis of Siliciclastic Sands and Muds. Journal of Geology, 105, 173-191. http://dx.doi.org/10.1086/515908

[58] Nesbitt, H.W. and Young, G.M. (1982) Early Proterozoic Climates and Plate Motions Inferred from Major Element Chemistry of Lutites. Nature, 299, 715-717. http://dx.doi.org/10.1038/299715a0

[59] Fedo, C.M., Nesbitt, H.W. and Young, G.M. (1995) Unraveling the Effects of Potassium Metasomatism in Sedimentary Rocks and Paleosols, with Implications for Paleoweathering Conditions and Provenance. Geology, 23, 921-924. http://dx.doi.org/10.1130/0091-7613(1995)023<0921:UTEOPM>2.3.CO;2

[60] Farzadi, P. (2006) The Development of Middle Cretaceous Carbonate Platforms, Persian Gulf, Iran: Constraints from Seismic Stratigraphy, Well and Biostratigraphy. Petroleum Geoscience, 12, 59-68. http://dx.doi.org/10.1144/1354-079305-654

[61] Piryaei, A., Reijmer, J.J.G., van Buchem, F.S.P., Yazdi-Moghadam, M., Sadouni, J. and Danelian, T. (2010) The Influence of Late Cretaceous Tectonic Processes on Sedimentation Patterns along the Northeastern Arabian Plate Margin (Fars Province, SW Iran). Geological Society, London, Special Publications, 330, 211-251. http://dx.doi.org/10.1144/SP330.11

[62] Harris, P.M., Frost, S.H., et al. (1984) Regional Unconformities and Depositional Cycles; Cretaceous of the Arabian Peninsula. In: Schlee, J.S., Ed., Interregional Unconformities and Hydrocarbon Accumulations, AAPG Mem., 36, 6780 .

[63] Alsharhan, A.S. and Kendall, C.G.St.C. (1991) Cretaceous Chronostratigraphy, Unconformities, and Eustatic SeaLevel Changes in the Sediments of Abu Dhabi. Cretaceous Research, 12, 379-401. http://dx.doi.org/10.1016/0195-6671(91)90016-6

[64] Entsminger, L.D. (1981) Sedimentary Response to Tectonic and Eustatic Changes: An Example from the Mid-Cretaceous Formation, Saudi Arabia. 2nd SPE Middle East Oil Show (Bahrain), SPE 9592, 159-169.

[65] Murris, R.J. (1981) Middle East: Stratigraphic Evolution and Oil Habitat. Geologie en Mijnbouw, 60, 467-486.

[66] Alsharhan, A.S. and Nairn, A.E.M. (1988) Review of the Cretaceous Formations in the Arabian Peninsula and Gulf: Part II. Mid-Cretaceous (Wasia Group) Stratigraphy and Paleogeography. Journal of Petroleum Geology, 11, 89-112. http://dx.doi.org/10.1111/j.1747-5457.1988.tb00803.x

[67] Ziegler, M.A. (2001) Late Permian to Holocene Paleofacies Evolution of the Arabian Plate and its Hydrocarbon Occurrences. GeoArabia, 6, 445-450. 


\section{Appendix 1}

Table S1. Major elements composition of the Late Lower Cretaceous (Albian) Kazhdumi Formation sandstones at Soroosh (S-1 to S-18 samples), Nowrooz (N-1 to N-6 samples), Foroozan (F-1 to F-6 samples) and Hendijan (H-1 to H-5 samples) oil fields (oxides in \%).

\begin{tabular}{|c|c|c|c|c|c|c|c|c|c|c|c|c|c|c|c|c|c|c|}
\hline S.N & ${ }^{*} \mathrm{~S}-1$ & 'S-2 & ${ }^{*} \mathrm{~S}-3$ & S-4 & S-5 & ${ }^{*} \mathrm{~S}-6$ & S-7 & S-8 & S-9 & S-10 & S-11 & S-12 & S-13 & S-14 & 'S-15 & ${ }^{*} \mathrm{~S}-16$ & S-17 & S18 \\
\hline $\mathrm{SiO}_{2}$ & 53.7 & 19.1 & 51.8 & 36.5 & 96.7 & 45.8 & 80.0 & 96.8 & 97.1 & 84.0 & 96.5 & 87.7 & 96.7 & 92.8 & 15.5 & 47.4 & 70.7 & 76.2 \\
\hline $\mathbf{A l}_{2} \mathbf{O}_{3}$ & 19.8 & 11.0 & 21.0 & 4.8 & 0.7 & 23.5 & 8.1 & 0.2 & 0.4 & 6.3 & 0.5 & 4.8 & 0.7 & 0.8 & 11.2 & 27.5 & 9.3 & 8.2 \\
\hline $\mathrm{Fe}_{2} \mathrm{O}_{3}$ & 8.2 & 39.9 & 8.7 & 34.0 & 1.0 & 6.3 & 2.3 & 1.3 & 0.4 & 1.6 & 0.4 & 1.1 & 0.6 & 2.5 & 36.8 & 6.2 & 5.5 & 5.1 \\
\hline MgO & 1.1 & 1.9 & 0.6 & 2.1 & $<0.1$ & 0.6 & 0.2 & $<0.1$ & $<0.1$ & 0.1 & $<0.1$ & 0.1 & - & $<0.1$ & 1.2 & 0.4 & 0.5 & 0.7 \\
\hline $\mathrm{CaO}$ & 0.3 & 2.3 & 0.5 & 2.4 & 0.2 & 0.3 & 0.2 & 0.2 & 0.2 & 0.2 & 0.3 & 0.2 & 0.1 & 0.4 & 3.3 & 0.2 & 0.4 & 0.6 \\
\hline $\mathrm{SO}_{3}$ & 1.4 & 0.7 & 1.2 & 0.3 & 0.1 & 2.0 & 1.7 & 0.1 & 0.1 & 1.3 & 0.1 & 0.5 & 0.1 & 0.2 & 0.5 & 1.5 & 3.4 & 1.3 \\
\hline $\mathbf{K}_{2} \mathbf{O}$ & 0.8 & 0.2 & 0.5 & 0.1 & 0.1 & 0.8 & 0.4 & $<0.1$ & $<0.1$ & 0.2 & $<0.1$ & 0.1 & $<0.1$ & $<0.1$ & 0.1 & 0.5 & 0.6 & 0.6 \\
\hline $\mathrm{Na}_{2} \mathrm{O}$ & 0.7 & 0.7 & 0.6 & 0.5 & 0.1 & 0.6 & 0.4 & $<0.1$ & 0.1 & 0.4 & 0.3 & 0.4 & 0.1 & 0.2 & 0.5 & 0.5 & 0.8 & 1.0 \\
\hline $\mathrm{TiO}_{2}$ & 1.9 & 0.5 & 1.6 & 0.2 & 0.1 & 1.6 & 1.0 & $<0.1$ & 0.1 & 0.7 & $<0.1$ & 0.5 & 0.2 & 0.1 & 0.2 & 1.9 & 0.9 & 0.5 \\
\hline $\mathbf{P}_{2} \mathbf{O}_{5}$ & 0.1 & 1.0 & 0.1 & 0.5 & $<0.1$ & 0.1 & 0.1 & $<0.1$ & $<0.1$ & 0.1 & $<0.1$ & $<0.1$ & $<0.1$ & $<0.1$ & 1.7 & 0.1 & 0.2 & 0.1 \\
\hline $\mathrm{CuO}$ & 0.4 & $<0.1$ & $<0.1$ & $<0.1$ & - & 0.7 & - & - & - & - & - & $<0.1$ & - & - & - & $<0.1$ & $<0.1$ & $<0.1$ \\
\hline Cl & 0.6 & 0.8 & 0.5 & 0.6 & 0.2 & 0.5 & 0.5 & 0.1 & 0.1 & 0.6 & 0.5 & 0.6 & 0.2 & 0.4 & 0.3 & 0.4 & 1.1 & 1.1 \\
\hline MnO & $<0.1$ & 0.2 & $<0.1$ & 0.2 & - & $<0.1$ & - & $<0.1$ & - & - & - & $<0.1$ & - & - & 0.2 & - & $<0.1$ & - \\
\hline $\mathrm{BaO}$ & - & - & $<0.1$ & - & - & - & - & $<0.1$ & $<0.1$ & - & $<0.1$ & $<0.1$ & $<0.1$ & $<0.1$ & - & - & $<0.1$ & - \\
\hline SrO & $<0.1$ & $<0.1$ & $<0.1$ & $<0.1$ & - & 0.0 & $<0.1$ & $<0.1$ & $<0.1$ & - & $<0.1$ & $<0.1$ & $<0.1$ & $<0.1$ & $<0.1$ & $<0.1$ & $<0.1$ & $<0.1$ \\
\hline $\mathrm{ZrO}_{2}$ & 0.1 & $<0.1$ & 0.1 & $<0.1$ & $<0.1$ & 0.1 & 0.2 & $<0.1$ & $<0.1$ & 0.1 & $<0.1$ & $<0.1$ & $<0.1$ & $<0.1$ & $<0.1$ & 0.1 & 0.1 & $<0.1$ \\
\hline L.O.I & 10.56 & 21.29 & 12.38 & 17.27 & 0.52 & 16.92 & 4.58 & 0.96 & 0.92 & 3.78 & 1 & 3.65 & 0.82 & 2.23 & 28.05 & 12.85 & 6.02 & 4.13 \\
\hline S.N & ${ }^{*} \mathrm{~N}-1$ & $\mathrm{~N}-2$ & ${ }^{*} \mathrm{~N}-3$ & $\mathrm{~N}-4$ & N-5 & ${ }^{*} \mathrm{~N}-6$ & F-1 & F-2 & F-3 & F-4 & F-5 & F-6 & H-1 & ${ }^{\circ} \mathrm{H}-2$ & H-3 & $\mathrm{H}-4$ & $\mathrm{H}-5$ & \\
\hline $\mathrm{SiO}_{2}$ & 76.2 & 44.7 & 41.7 & 73.3 & 82.2 & 41.1 & 40.4 & 53.6 & 50.7 & 54.1 & 48.6 & 64.6 & 50.4 & 22.1 & 48.0 & 41.8 & 43.5 & \\
\hline $\mathbf{A l}_{2} \mathbf{O}_{3}$ & 10.4 & 23.7 & 22.9 & 6.5 & 7.7 & 24.1 & 11.7 & 10.8 & 8.4 & 9.9 & 5.9 & 4.4 & 23.8 & 11.0 & 26.2 & 4.6 & 8.7 & \\
\hline $\mathrm{Fe}_{2} \mathrm{O}_{3}$ & 2.0 & 4.6 & 7.5 & 4.1 & 1.6 & 4.1 & 7.3 & 5.6 & 5.0 & 3.4 & 2.8 & 2.3 & 7.0 & 15.3 & 5.3 & 21.3 & 24.5 & \\
\hline MgO & 0.3 & 0.3 & 0.4 & $<0.1$ & $<0.1$ & 0.3 & 0.5 & 0.3 & 0.4 & 0.3 & 0.3 & 0.2 & 0.5 & 1.0 & 0.5 & 1.4 & 1.1 & \\
\hline $\mathrm{CaO}$ & 0.1 & 0.6 & 0.6 & 0.4 & 0.2 & 0.4 & 11.2 & 6.2 & 11.5 & 8.8 & 8.7 & 9.0 & 0.4 & 22.4 & 1.8 & 10.8 & 3.0 & \\
\hline $\mathrm{SO}_{3}$ & 0.9 & 1.6 & 1.3 & 6.2 & 1.5 & 0.8 & 2.1 & 1.8 & 2.1 & 1.5 & 1.4 & 1.4 & 1.4 & 3.3 & 1.0 & 0.3 & 0.5 & \\
\hline $\mathbf{K}_{2} \mathbf{O}$ & 0.7 & 0.5 & 0.4 & 0.1 & 0.3 & 0.5 & 0.4 & 0.4 & 0.3 & 0.3 & 0.2 & 0.2 & 1.1 & 0.5 & 1.2 & 0.1 & 0.2 & \\
\hline $\mathrm{Na}_{2} \mathrm{O}$ & 0.7 & 0.4 & 0.5 & 0.4 & 0.2 & 0.4 & 0.9 & 1.1 & 0.9 & 1.1 & 4.3 & 1.0 & 0.4 & 0.3 & 0.4 & 0.3 & 0.6 & \\
\hline $\mathrm{TiO}_{2}$ & 0.8 & 1.9 & 1.6 & 0.4 & 0.9 & 1.4 & 0.8 & 0.6 & 0.6 & 0.9 & 0.6 & 0.4 & 1.8 & 0.8 & 1.6 & 0.2 & 0.4 & \\
\hline $\mathbf{P}_{2} \mathbf{O}_{5}$ & $<0.1$ & 0.1 & 0.2 & 0.1 & $<0.1$ & 0.1 & 0.1 & 0.1 & 0.1 & 0.1 & $<0.1$ & $<0.1$ & 0.2 & 0.2 & 0.1 & 0.2 & 0.5 & \\
\hline $\mathrm{CuO}$ & - & $<0.1$ & - & $<0.1$ & - & - & - & $<0.1$ & - & - & - & $<0.1$ & - & - & - & - & - & \\
\hline Cl & 0.9 & 0.5 & 0.6 & 0.4 & 0.7 & 0.4 & 2.3 & 2.4 & 2.4 & 2.9 & 8.1 & 2.6 & 0.1 & 0.1 & 0.1 & 0.3 & 0.6 & \\
\hline MnO & - & - & $<0.1$ & - & - & - & $<0.1$ & $<0.1$ & $<0.1$ & $<0.1$ & $<0.1$ & $<0.1$ & $<0.1$ & 0.2 & $<0.1$ & 0.1 & 0.2 & \\
\hline BaO & - & - & - & $<0.1$ & $<0.1$ & - & 1.2 & 1.1 & 1.7 & 1.3 & 1.2 & 1.3 & - & $<0.1$ & - & $<0.1$ & $<0.1$ & \\
\hline SrO & $<0.1$ & $<0.1$ & $<0.1$ & $<0.1$ & $<0.1$ & $<0.1$ & 0.1 & $<0.1$ & 0.1 & 0.1 & 0.1 & 0.1 & $<0.1$ & 0.1 & $<0.1$ & $<0.1$ & $<0.1$ & \\
\hline $\mathrm{ZrO}_{2}$ & 0.1 & 0.1 & 0.1 & $<0.1$ & 0.1 & $<0.1$ & $<0.1$ & 0.1 & $<0.1$ & 0.1 & $<0.1$ & $<0.1$ & 0.1 & $<0.1$ & 0.1 & $<0.1$ & $<0.1$ & \\
\hline L.O.I & 6.55 & 20.76 & 21.86 & 7.79 & 4.02 & 25.76 & 20.55 & 15.47 & 15.54 & 14.77 & 17.35 & 12.08 & 12.36 & 22.19 & 13.18 & 18.14 & 15.79 & \\
\hline
\end{tabular}

*Shaly samples; ‘Sideritic Sandstone; ${ }^{\circ}$ Dolomitic Sandstone. 


\section{Appendix 2}

Table S2. Whole rock trace element composition of representative Late Lower Cretaceous (Albian) Kazhdumi Formation sandstones at Soroosh, Nowrooz, Foroozan and Hendijan oil fields. Elemental concentrations are parts per million (ppm).

\begin{tabular}{|c|c|c|c|c|c|c|c|c|c|c|c|c|c|c|c|c|c|c|}
\hline Samples & ${ }^{*} \mathrm{~S}-1$ & 'S-2 & ${ }^{*} \mathrm{~S}-3$ & 'S-4 & S-5 & ${ }^{*} \mathrm{~S}-6$ & S-7 & S-8 & S-9 & S-10 & S-11 & S-12 & S-13 & S-14 & 'S-15 & ${ }^{*} \mathrm{~S}-16$ & S-17 & S18 \\
\hline Ba & 113 & 45.79 & 157 & 25.44 & 271 & 140 & 74.20 & 1926 & 1378 & 233 & 1575 & 73.07 & 990 & 1267 & 50.06 & 159 & 188 & 196 \\
\hline Co & 25.54 & 38.26 & 25.01 & 16.00 & 4.06 & 22.18 & 13.38 & 1.50 & 2.03 & 10.72 & 2.09 & 9.18 & 4.64 & 2.74 & 20.63 & 27.97 & 16.02 & 11.51 \\
\hline $\mathrm{Cr}$ & 195 & 66.35 & 116 & 214 & 40.26 & 73.24 & 218 & 118 & 113 & 158 & 100 & 362 & 259 & 142 & 50.81 & 75.47 & 100 & 131 \\
\hline $\mathrm{Cu}$ & 2761 & 172 & 156 & 119 & 17.00 & 5131 & 13.55 & 12.37 & 16.01 & 30.70 & 10.48 & 202 & 13.95 & 33.73 & 1.68 & 289 & 12.36 & 82.45 \\
\hline Hf & 5.48 & 10.67 & 5.88 & 6.33 & $<2$ & 7.30 & 2.62 & $<2$ & $<2$ & $<2$ & $<2$ & $<2$ & $<2$ & $<2$ & 9.61 & 6.99 & 2.69 & 3.00 \\
\hline La & 38.37 & 69.47 & 42.24 & 32.54 & 5.27 & 68.01 & 39.67 & 4.16 & 4.96 & 34.57 & 4.26 & 14.04 & 8.34 & 6.96 & 81.02 & 63.21 & 32.91 & 27.21 \\
\hline Nb & 42.80 & 60.06 & 40.13 & 19.09 & 2.18 & 42.27 & 20.53 & $<1$ & 1.87 & 16.90 & $<1$ & 10.28 & 4.59 & 2.51 & 43.00 & 51.25 & 15.28 & 11.10 \\
\hline $\mathrm{Ni}$ & 39.87 & 105 & 53.62 & 67.11 & 8.43 & 47.68 & 22.58 & 19.16 & 7.59 & 27.73 & 9.46 & 15.80 & 13.21 & 18.56 & 90.09 & 52.81 & 33.83 & 36.68 \\
\hline $\mathbf{P b}$ & 68.11 & 24.51 & 35.88 & 10.34 & 50.47 & 13.83 & 17.82 & 11.76 & 11.29 & 16.05 & 7.61 & 11.33 & 10.96 & 52.15 & 18.92 & 41.02 & 18.02 & 6.61 \\
\hline $\mathbf{R b}$ & 86.84 & 349 & 96.78 & 235 & 63.57 & 88.80 & 69.79 & 75.50 & 61.96 & 66.74 & 75.57 & 60.74 & 69.00 & 89.04 & 370 & 82.98 & 89.82 & 89.75 \\
\hline Sc & 14.15 & 35.92 & 15.29 & 10.57 & 0.70 & 19.09 & 8.39 & 0.51 & 0.79 & 6.39 & 0.73 & 4.94 & 1.30 & 1.89 & 38.19 & 19.67 & 8.31 & 10.00 \\
\hline $\mathrm{Sr}$ & 106 & 212 & 102 & 106 & 26.29 & 145 & 61.98 & 73.55 & 62.72 & 58.22 & 80.27 & 52.36 & 60.45 & 70.28 & 249 & 148 & 73.29 & 100 \\
\hline Th & 33.4 & 132 & 33.6 & 86.6 & 2.9 & 34.3 & 21.0 & 6.4 & 0.8 & 17.1 & 1.4 & 7.0 & 2.6 & 9.7 & 142 & 34.1 & 23.6 & 19.4 \\
\hline $\mathbf{T i}$ & $>10,000$ & 4002 & $>10,000$ & 1431 & 1219 & $>10,000$ & 6739 & 290 & 1375 & 6010 & 475 & 4213 & 2694 & 1088 & 2408 & $>10,000$ & 6422 & 4144 \\
\hline $\mathbf{U}$ & 4.01 & 28.33 & 4.38 & 17.95 & $<1$ & 3.08 & 1.09 & 1.03 & $<1$ & $<1$ & $<1$ & $<1$ & $<1$ & 1.79 & 28.30 & 2.62 & 2.83 & 2.79 \\
\hline V & 102 & 561 & 124 & 210 & 6.21 & 122 & 53.35 & 3.84 & 5.80 & 40.36 & 4.41 & 34.54 & 11.02 & 16.44 & 407 & 144 & 57.51 & 61.01 \\
\hline $\mathbf{Y}$ & 28.96 & 162 & 35.81 & 45.88 & 2.55 & 35.30 & 28.22 & 2.52 & 3.41 & 22.52 & 2.66 & 12.62 & 6.78 & 9.34 & 156 & 36.55 & 25.39 & 21.64 \\
\hline Zn & 77.95 & 83.30 & 112 & 63.73 & 14.02 & 98.10 & 43.63 & 18.45 & 16.91 & 43.50 & 23.59 & 38.25 & 13.52 & 25.45 & 80.70 & 98.01 & 72.17 & 131 \\
\hline $\mathrm{Zr}$ & 836 & 447 & 789 & 182 & 77.65 & 643 & 759 & 54.32 & 104 & 690 & 81.39 & 320 & 206 & 92.83 & 331 & 889 & 667 & 301 \\
\hline Samples & ${ }^{*} \mathrm{~N}-1$ & $\mathrm{~N}-2$ & ${ }^{*} \mathrm{~N}-3$ & $\mathrm{~N}-4$ & N-5 & ${ }^{*} \mathrm{~N}-6$ & F-1 & F-2 & F-3 & F-4 & F-5 & F-6 & H-1 & ${ }^{\circ} \mathrm{H}-2$ & H-3 & $\mathrm{H}-4$ & H-5 & \\
\hline Ba & 92.15 & 610 & 146 & 1511 & 139 & 136 & 7992 & 7476 & $>10,000$ & 9374 & $>10,000$ & $>10,000$ & 212 & 117 & 194 & 35.36 & 47.58 & \\
\hline Co & 12.81 & 25.43 & 24.85 & 11.11 & 12.45 & 24.00 & 15.50 & 19.57 & 10.33 & 13.45 & 6.94 & 6.61 & 31.13 & 23.12 & 27.76 & 14.90 & 25.03 & \\
\hline $\mathrm{Cr}$ & 33.15 & 43.48 & 106 & 120 & 36.35 & 98.11 & 133 & 120 & 97.65 & 118 & 152 & 58.65 & 59.67 & 39.01 & 123 & 147 & 31.81 & \\
\hline $\mathrm{Cu}$ & 18.50 & 156 & 10.95 & 81.13 & 14.24 & 31.00 & 55.65 & 66.03 & 36.78 & 39.16 & 57.42 & 40.16 & 27.36 & 14.00 & 28.51 & 1.43 & 2.45 & \\
\hline Hf & 2.71 & 7.30 & 6.96 & 2.74 & 2.16 & 5.98 & 6.25 & 5.15 & 4.59 & 4.84 & 3.68 & 3.57 & 6.60 & 7.79 & 7.58 & 5.63 & 6.26 & \\
\hline $\mathbf{L a}$ & 39.18 & 66.16 & 62.44 & 18.13 & 35.98 & 53.08 & 38.22 & 39.39 & 29.66 & 32.83 & 21.61 & 18.34 & 52.90 & 42.89 & 55.41 & 36.69 & 49.02 & \\
\hline Nb & 68.48 & 45.69 & 43.03 & 6.19 & 17.76 & 44.73 & 25.61 & 23.67 & 17.21 & 24.50 & 16.24 & 12.46 & 52.93 & 18.72 & 49.30 & 15.68 & 39.65 & \\
\hline $\mathbf{N i}$ & 21.62 & 42.92 & 47.98 & 31.14 & 21.22 & 43.97 & 52.83 & 43.77 & 37.20 & 35.64 & 31.25 & 29.74 & 55.94 & 68.85 & 55.73 & 69.35 & 69.60 & \\
\hline $\mathbf{P b}$ & 19.24 & 23.60 & 31.28 & 9.03 & 9.96 & 138 & 132 & 132 & 131 & 147 & 136 & 13.24 & 30.29 & 14.45 & 24.09 & 27.70 & 32.46 & \\
\hline $\mathbf{R b}$ & 63.91 & 82.29 & 105 & 91.86 & 66.42 & 76.31 & 187 & 162 & 162 & 156 & 147 & 150 & 87.07 & 273 & 116 & 240 & 241 & \\
\hline Sc & 9.85 & 17.59 & 21.98 & 4.73 & 6.89 & 21.48 & 13.82 & 13.01 & 9.14 & 10.99 & 6.67 & 4.88 & 23.79 & 30.47 & 25.59 & 9.97 & 23.32 & \\
\hline $\mathrm{Sr}$ & 70.05 & 162 & 167 & 106 & 60.53 & 196 & 605 & 485 & 632 & 557 & 566 & 619 & 139 & 538 & 164 & 227 & 161 & \\
\hline Th & 14.1 & 27.2 & 34.3 & 20.1 & 17.1 & 21.1 & 27.1 & 25.3 & 19.0 & 16.3 & 13.6 & 9.5 & 27.1 & 45.2 & 22.5 & 62.9 & 85.9 & \\
\hline Ti & 6130 & $>10,000$ & $>10,000$ & 3026 & 6791 & $>10,000$ & 6308 & 6261 & 4604 & 7596 & 4323 & 3305 & $>10,000$ & 5802 & $>10,000$ & 1737 & 3317 & \\
\hline $\mathbf{U}$ & $<1$ & 1.41 & 3.59 & 3.29 & $<1$ & 1.36 & 4.01 & 3.44 & 2.43 & 1.79 & 1.50 & 1.23 & 2.93 & 8.83 & 2.06 & 11.06 & 14.68 & \\
\hline $\mathbf{V}$ & 71.13 & 125 & 120 & 27.19 & 44.43 & 154 & 106 & 101 & 59.83 & 58.46 & 37.68 & 30.71 & 152 & 86.13 & 155 & 137 & 318 & \\
\hline $\mathbf{Y}$ & 25.09 & 39.70 & 47.40 & 11.93 & 23.61 & 34.95 & 33.75 & 32.68 & 23.30 & 25.71 & 16.64 & 12.98 & 39.79 & 61.40 & 39.70 & 35.08 & 62.46 & \\
\hline Zn & 60.31 & 59.63 & 42.69 & 26.22 & 64.97 & 81.65 & 190 & 137 & 166 & 124 & 139 & 137 & 89.66 & 384 & 89.84 & 37.92 & 130 & \\
\hline $\mathrm{Zr}$ & 527 & 880 & 795 & 222 & 792 & 661 & 467 & 463 & 337 & 540 & 357 & 280 & 802 & 397 & 657 & 190 & 357 & \\
\hline
\end{tabular}

*Shaly samples; 'Sideritic Sandstone; ${ }^{\circ}$ Dolomitic Sandston. 


\section{Submit or recommend next manuscript to SCIRP and we will provide best service for you:}

Accepting pre-submission inquiries through Email, Facebook, LinkedIn, Twitter, etc.

A wide selection of journals (inclusive of 9 subjects, more than 200 journals)

Providing 24-hour high-quality service

User-friendly online submission system

Fair and swift peer-review system

Efficient typesetting and proofreading procedure

Display of the result of downloads and visits, as well as the number of cited articles

Maximum dissemination of your research work

Submit your manuscript at: http://papersubmission.scirp.org/ 